\title{
Hydrogen Peroxide Metabolism in Interkingdom Interaction Between Bacteria and Wheat Seeds and Seedlings
}

\author{
Davide Gerna, ${ }^{1}$ Thomas Roach, ${ }^{1,+}$ Birgit Mitter, ${ }^{2}$ Wolfgang Stöggl, ${ }^{1}$ and Ilse Kranner ${ }^{1}$ \\ ${ }^{1}$ Department of Botany and Center for Molecular Biosciences Innsbruck (CMBI), University of Innsbruck, Innsbruck, Austria \\ ${ }^{2}$ Bioresources Unit, Austrian Institute of Technology GmbH (AIT), Tulln, Austria
}

Accepted 16 October 2019.

\begin{abstract}
In endophytes, the abundance of genes coding for enzymes processing reactive oxygen species (ROS), including hydrogen peroxide $\left(\mathrm{H}_{2} \mathrm{O}_{2}\right)$, argues for a crucial role of ROS metabolism in plant-microbe interaction for plant colonization. Here, we studied $\mathrm{H}_{2} \mathrm{O}_{2}$ metabolism of bread wheat (Triticum aestivum L.) seeds and their microbiota during germination and early seedling growth, the most vulnerable stages in the plant life cycle. Treatment with hot steam diminished the seed microbiota, and these seeds produced less extracellular $\mathrm{H}_{2} \mathrm{O}_{2}$ than untreated seeds. Using a culture-dependent approach, Pantoea and Pseudomonas genera were the most abundant epiphytes of dry untreated seeds. Incubating intact seedlings from hot steamtreated seeds with Pantoea strains triggered $\mathrm{H}_{2} \mathrm{O}_{2}$ production, whereas Pseudomonas strains dampened $\mathrm{H}_{2} \mathrm{O}_{2}$ levels, attributable to higher catalase activities. The genus Pantoea was much less represented among seedling endophytes than genus Pseudomonas, with other endophytic genera, including Bacillus and Paenibacillus, also possessing high catalase activities. Overall, our results show that certain bacteria of the seed microbiota are able to modulate the extracellular redox environment during germination and early seedling growth, and high catalase activity is proposed as a key trait of seed endophytes.
\end{abstract}

Keywords: catalase, endophytes, epiphytes, microbiota, Pantoea agglomerans, Pantoea eucalypti, Pseudomonas fluorescens, Pseudomonas oryzihabitans, reactive oxygen species

We now understand plants as holobionts that continuously interact with their associated microbiota (Bordenstein and Theis 2015; Zilber-Rosenberg and Rosenberg 2008). The microbiota consists of all microorganisms colonizing any plant niche, and the

${ }^{\dagger}$ Corresponding author: T. Roach; thomas.roach@uibk.ac.at

Funding: This work was funded by the "Mountain Agriculture Research Project 2019" (grant P7170-041-011) of the University of Innsbruck. D. Gerna received financial support by the Seventh Framework Programme of the European Union "EcoSeed" (Impacts of Environmental Conditions on Seed Quality) grant 311840, the University of Innsbruck scholarship "Doktoratsstipendium NEU aus der Nachwuchsförderung 2015, 2. Tranche", and the Doctoral Programme "Ageing and Regeneration".

*The $\boldsymbol{e}$-Xtra logo stands for "electronic extra" and indicates that a supplementary figure is published online.

The author(s) declare no conflict of interest.

(C) 2020 The American Phytopathological Society sum of the genomes of the microbiota is defined as the microbiome (Brader et al. 2017). Seed-borne microbes represent the pioneer microbial community of the next plant generation and may play important roles in early plant growth and establishment, as well as affecting later microbial colonization from the soil microhabitat surrounding the seed, termed spermosphere (Barret et al. 2015; Nelson 2004; Rodríguez et al. 2018; Schiltz et al. 2015; Shade et al. 2017; Verma et al. 2019). Based on their colonization niche and irrespectively of their functions, seed microbiota are distinguished as epiphytes if they live on the seed surface (e.g., seed coat) and endophytes when they colonize internal seed tissues (termed endosphere), including embryo, endosperm, and eventually aleurone and perisperm (Nelson 2018).

Differently from other plant compartments such as the rhizosphere, the bacterial community of seeds is composed of a relatively limited number of phyla that are mostly grouped in the Proteobacteria, Firmicutes, and Actinobacteria (Hardoim et al. 2015; Nelson 2018; Santoyo et al. 2016). Seed microbiota may be intrinsically adapted to the seed habitat, thus surviving after seed maturation drying and eventually benefitting from solute leakage and storage nutrient mobilization upon germination (Barret et al. 2015; Bewley 1997; Mano et al. 2006). In the past decade, seed endophytes have received increasing attention regarding their vertical transmission routes (i.e., passing with the seed from one plant generation to the next). For instance, a cultureindependent analysis reveals that $45 \%$ of the endophytes in rice seeds of the first generation are subsequently found in the second generation (Hardoim et al. 2012). Using 16S ribosomal (r)RNA gene analyses, Cope-Selby et al. (2017) showed that about $30 \%$ of bacterial endophyte families are shared between adult plants and seedlings germinated from surface-sterilized seeds, also suggesting that vertical transmission contributes to the adult plant microbiome. Furthermore, genetic selection on seed endophyte diversity was assessed using the closest maize wild relative (Zea mays subsp. parviglumis), landraces, and modern maize (Zea mays L.) cultivars. A core maize seed microbiome was identified with high specificity of taxa (e.g., genera Clostridium, Paenibacillus), which are tightly associated within genus Zea (Johnston-Monje and Raizada 2011). Similarly, barley seeds of five cultivars share a great part of their microbiome, which includes genera Phyllobacterium, Paenibacillus, and Trabusiella (Yang et al. 2017). Recently, the seeds of Malus pumila were found to be a hot spot of microbial abundance, in comparison with other apple fruit tissues (Wassermann et al. 2019). Moreover, when wheat flowers are sprayed with a suspension of the bacterial endophyte Paraburkholderia 
phytofirmans PsJN, this strain is transmitted to the seeds, confirming vertical inheritance of endophytes via seed production (Mitter et al. 2017).

Numerous studies report on the beneficial effects of bacterial endophytic strains on plant growth and stress tolerance, possibly mediated by endophyte-derived metabolite secretion (Bergna et al. 2018; Brader et al. 2014; Díaz Herrera et al. 2016; Khare et al. 2018; Naveed et al. 2014; Shahzad et al. 2018). Differently from seed endophytes, studies on seed epiphytes were mostly directed toward their pathogenicity, which led to the development of various seed sanitation methods (Halmer 2006; Nelson 2018).

The "oxidative burst" (Lamb and Dixon 1997; McDowell and Dangl 2000; Wojtaszek 1997) is a well-known response of plant cells to microbial challenge, involving a rapid and transient apoplastic production of reactive oxygen species (ROS), mostly superoxide anion radical and hydrogen peroxide $\left(\mathrm{H}_{2} \mathrm{O}_{2}\right)$. The $\mathrm{H}_{2} \mathrm{O}_{2}$-mediated signaling cascades activated by microbes in plants are well-described at a cellular level (Bigeard et al. 2015; Garcia-Brugger et al. 2006; Nanda et al. 2010; Pel and Pieterse 2013). Only in few cases, microbetriggered $\mathrm{H}_{2} \mathrm{O}_{2}$ responses have been studied in seedlings (Lei et al. 2017; Morkunas et al. 2004). However, it is poorly understood if ROS production by seeds plays a role in interkingdom signaling with endophytes. In turn, the molecular mechanisms that enable a bacterium to adopt an endophytic lifestyle also remain unresolved. Compared with other microorganisms, the endophytes studied hitherto appear to have an elevated number of genes coding for ROS-processing enzymes, including catalases, which dismutate $\mathrm{H}_{2} \mathrm{O}_{2}$ to water and molecular oxygen (Kandel et al. 2017; Liu et al. 2017; Mitter et al. 2013; Pauly et al. 2006; Reinhold-Hurek and Hurek 2011; Sessitsch et al. 2012; Zamocky et al. 2008). In plants, ROS (e.g., $\mathrm{H}_{2} \mathrm{O}_{2}$ ) are part of signaling networks influencing the activity of plant hormones, such as gibberellins and abscisic acid (Kranner et al. 2010a; Weitbrecht et al. 2011). In seeds, ROS are implicated in endosperm weakening, cell-wall remodeling to support radicle protrusion, and programmed cell death in the aleurone layer of cereals (Bailly et al. 2008; Bahin et al. 2011; Kranner et al. 2010b; Mhamdi and Van Breusegem 2018; Wojtyla et al. 2016). Furthermore, mitochondrial respiration, $\beta$-oxidation of fatty acids, alongside activities of NADPH oxidases, oxalate oxidases, amine oxidases, and extracellular peroxidases can all contribute to $\mathrm{H}_{2} \mathrm{O}_{2}$ production during seed germination (Gerna et al. 2017; Ishibashi et al. 2010; Kranner et al. 2010a; Li et al. 2017; Roach et al. 2010, 2015). Nonetheless, the influence of microbes on $\mathrm{H}_{2} \mathrm{O}_{2}$ metabolism in seeds and seedlings has not been appreciated.

Here, we used a culture-dependent approach to elucidate $\mathrm{H}_{2} \mathrm{O}_{2}$ metabolism associated with the interaction between seeds and their native epiphytes or endophytes during germination and early seedling growth, focusing on bacteria. We hypothesized that seed-borne microbiota induce $\mathrm{H}_{2} \mathrm{O}_{2}$ production (i.e., an oxidative burst) by seeds during germination. We chose to use seeds of bread wheat (Triticum aestivum L.), one of the most important crops globally (the FAO website; Laino et al. 2015), and the naturally occurring microbiota that they host. The production of $\mathrm{H}_{2} \mathrm{O}_{2}$ was compared between seeds treated with hot steam, a method of seed-surface sterilization obviating the use of chemicals affecting the seed redox state (e.g., $\mathrm{H}_{2} \mathrm{O}_{2}$, sodium hypochlorite), and untreated control seeds. Epiphytes were isolated from dry control seeds and were used to inoculate intact seedlings from hot steam-treated seeds, to study and quantify subsequent oxidative $\mathrm{H}_{2} \mathrm{O}_{2}$ production. Finally, the $\mathrm{H}_{2} \mathrm{O}_{2}$ metabolism of these epiphytic bacterial strains was assessed. Altogether, our results provide physiological and biochemical evidence that breaking down $\mathrm{H}_{2} \mathrm{O}_{2}$ via catalase is implicated in the interaction of bacteria with the seedling endosphere.

\section{RESULTS}

Hot steam-treated seeds produced less $\mathrm{H}_{2} \mathrm{O}_{2}$.

The hot steam treatment (Fig. 1A) affected $\mathrm{H}_{2} \mathrm{O}_{2}$ production in bread wheat seeds and seedlings (Fig. 1B). After the hot steam treatment, seeds and seedlings produced between 1.9fold to 1.2-fold less $\mathrm{H}_{2} \mathrm{O}_{2}$ than untreated (control) seeds and seedlings at the same timepoint (Fig. 1B). First radicle protrusion was observed $12 \mathrm{~h}$ after the onset of imbibition, and, after $48 \mathrm{~h}$, all viable seeds had germinated and produced seedlings (Supplementary Fig. S1). Prior to completion of germination, nitroblue tetrazolium chloride (NBT) staining indicated that ROS production was mostly localized in the coleorhiza and areas around the embryo, whereas, at the seedling stage, ROS were produced by the roots but not by the seed coat, coleoptile, or first foliage leaves (Fig. 1C and D).

\section{Isolates of seed epiphytes comprised \\ families Enterobacteriaceae and Pseudomonadaceae.}

Quantifying the colony-forming units isolated from the surface of seeds showed that hot steam-treated seeds hosted around 10-fold fewer culturable seed epiphytes than control seeds (Fig. 2A). Eighteen bacterial isolates obtained from the surfaces of dry control seeds were identified using 16S rRNA gene sequencing, showing that they were members of class Gammaproteobacteria. Approximately 69 and $31 \%$ were assigned to families Enterobacteriaceae and Pseudomonadaceae, respectively (Fig. 2D; Table 1). To identify different strains, PCR amplification of the hypervariable intergenic spacer (IGS) region of the 16S-23S rDNA operon, followed by restriction fragment length polymorphism (RFLP) analyses, was combined with DNA gyrase subunit B ( gyrB) gene sequencing. RFLP of IGS amplicons of the epiphytic Enterobacteriaceae spp. distinguished two clear ribotypes, suggesting that the epiphytic isolates corresponded to at least two different strains, as confirmed by $\operatorname{gyr} B$ sequencing (Table 1). Nine isolates of the same strain (approximately $82 \%$ of the Enterobacteriaceae spp.) were most closely related to Pantoea agglomerans, and two isolates of the same strain (approximately $18 \%$ of the Enterobacteriaceae spp.) to Pantoea eucalypti (Table 1).

Among the Pseudomonadaceae spp., three of five isolates showed identical IGS RFLP ribotypes, indicating that they were closely related. Sequence alignments of $g y r B$ attributed this common ribotype to two different strains of Pseudomonas oryzihabitans (NT0-1 and NT0-6). Furthermore, two additional Pseudomonadaceae isolates exhibited slightly different ribotypes, and $g y r B$ sequencing indeed assigned them to the distinct strains NT0-2 and NT0-8 of Pseudomonas fluorescens (Table 1). The remaining isolates belonged to two additional ribotypes, which differed from the other three and between each other. Analyses of $g y r B$ sequences of these isolates revealed values of similarity with known species lower than $97 \%$, which did not allow reliable identification.

\section{Seedlings from hot steam-treated seeds hosted fewer culturable epiphytes and endophytes.}

Compared with dry seeds, the number of epiphytic colonyforming units exponentially rose $10^{4}$-fold in seedlings $48 \mathrm{~h}$ after the onset of imbibition (Fig. 2A and B). Furthermore, seedlings from control seeds hosted about 2.3-fold more epiphytic colony-forming units than seedlings from hot steamtreated seeds (Fig. 2B), indicating that the hot steam treatment applied to dry seeds resulted in lower microbial load also at the seedling stage. Additionally, 16S rRNA gene sequencing of selected culturable epiphytic isolates of seedlings from control 
seeds revealed an increase in the genus diversity of the epiphytes compared with dry seeds. The majority of the isolates were class Gammaproteobacteria of the genera Pantoea and Pseudomonas, but isolates of phylum Firmicutes genus
Paenibacillus and of phylum Actinobacteria genus Rhodococcus were also identified (Fig. 2D).

For isolating endophytes, control and hot steam-treated seeds were chemically surface sterilized. This procedure
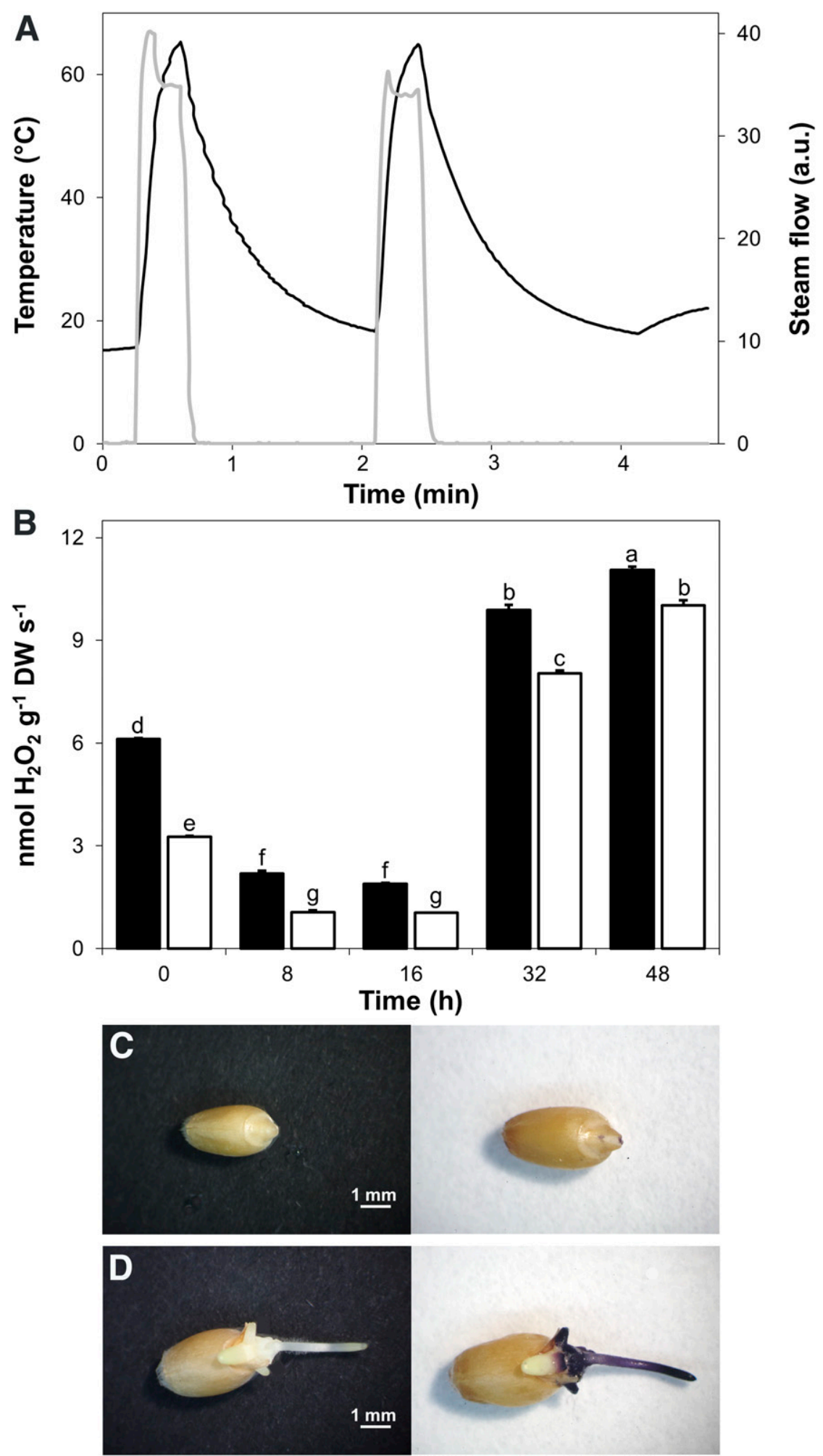

Fig. 1. Hot steam treatment decreased hydrogen peroxide $\left(\mathrm{H}_{2} \mathrm{O}_{2}\right)$ production by wheat seeds during germination and seedling growth. A, Conditions during the hot steam treatment prior to seed imbibition. Gray and black curves indicate intensity of the steam flow and temperature, respectively. $\mathbf{B}$, Production of $\mathrm{H}_{2} \mathrm{O}_{2}$ by untreated control (black) and hot steam-treated (white) seeds from the onset of imbibition $(0 \mathrm{~h})$ until attainment of total germination $(48 \mathrm{~h})$. Data are means \pm standard error (three replicates of 20 seeds). Bars labeled with the same letters do not differ significantly (one-way analyses of variance followed by post hoc Tukey's honest significant difference test, $\alpha=0.05$ ). C, Visualization of nitroblue tetrazolium chloride (NBT) staining (right side, white background) in seed tissues $8 \mathrm{~h}$ after the onset of imbibition and $\mathbf{D}$, in seedling tissues $48 \mathrm{~h}$ after the onset of imbibition. Dark purple staining indicates the production of reactive oxygen species. The corresponding samples before NBT staining are shown to the left. 
thoroughly eliminated seed epiphytes from both seed types, as revealed by the absence of colony-forming units. Independent of the hot steam treatment, endophytes were only culturable from seedlings but not from dry seeds, and seedlings from hot steam-treated seeds hosted 75-fold fewer endophytes than seedlings from control seeds (Fig. 2C). Sequencing the 16S rRNA genes of culturable endophytic isolates revealed the presence of both firmicutes (approximately 41\%) and gammaproteobacteria (approximately 59\%). Among the first group, isolates of the genera Bacillus and Paenibacillus were identified, and within class Gammaproteobacteria, the genus Pseudomonas dominated over the genus Pantoea (Fig. 2D). Finally, the last two endophytic isolates were assigned to the genera Kosakonia and Stenotrophomonas (Fig. 2D).

In summary, compared with dry seeds, genera diversity of culturable bacteria increased in the seedling bacterial community. The only two epiphytic genera isolated from dry seeds were Pantoea and Pseudomonas. In seedlings, all genera of epiphytic isolates, except Rhodococcus sp., were also identified in the endophytic pool. Particularly, the genus Pantoea appeared to dominate the epiphytic community. However, the genus Pseudomonas was also found in the seedling epiphytic community and was the most represented endophyte (Fig. 2D).

\section{Effects of seedling inoculation with Pantoea and} Pseudomonas strains on $\mathrm{H}_{2} \mathrm{O}_{2}$ metabolism.

Seedlings from hot steam-treated seeds, with a significantly decreased microbial load compared with seedlings from control seeds $(P=0.016$ for epiphytes and $P<0.001$ for endophytes), were utilized to elucidate whether early interactions between seedlings and seed microbiota affected $\mathrm{H}_{2} \mathrm{O}_{2}$ metabolism (Fig. 3). These seedlings were inoculated with the bacterial strains $P$. agglomerans NT0-7 and NT0-11, P. eucalypti NT0-3 and NT04, Pseudomonas fluorescens NT0-2 and NT0-8, and Pseudomonas oryzihabitans NT0-1 and NT0-6 isolated from the surface of dry control seeds and assigned to distinct IGS RFLP groups (Table 1).

Seedlings grown from hot steam-treated seeds produced approximately $0.91 \pm 0.05$ (standard error) pmol $\mathrm{H}_{2} \mathrm{O}_{2} \mathrm{~s}^{-1} 48 \mathrm{~h}$ after the onset of imbibition. The $\mathrm{H}_{2} \mathrm{O}_{2}$ levels increased by around 2.1-fold upon inoculation with $P$. agglomerans NT0-7 and NT0-11 or P. eucalypti NT0-3 and NT0-4, compared with seedlings incubated in sterilized tryptic soy broth (TSB) medium, included as control (Fig. 3A and B; Table 1). For the Pantoea strains, maximal $\mathrm{H}_{2} \mathrm{O}_{2}$ levels were detected $1 \mathrm{~h}$ after seedling inoculation, before returning to levels similar to those measured in control seedlings (Fig. 3A and B). In contrast, seedling inoculation with Pseudomonas fluorescens NT0-2 and NT0-8 was not accompanied by any $\mathrm{H}_{2} \mathrm{O}_{2}$ burst. Instead, a 14-fold decrease in $\mathrm{H}_{2} \mathrm{O}_{2}$ production occurred $1 \mathrm{~h}$ after inoculation (Fig. 3C). Pseudomonas oryzihabitans NT0-1 and NT0-6 interacted differently with seedlings, whereby only Pseudomonas oryzihabitans NT0-1 induced an $\mathrm{H}_{2} \mathrm{O}_{2}$ burst after $1 \mathrm{~h}$, before both strains decreased $\mathrm{H}_{2} \mathrm{O}_{2}$ levels around 3.6-fold below those of control seedlings starting from $1.5 \mathrm{~h}$ after inoculation (Fig. 3D).

In summary, these results indicated that the early interaction between a seedling and seed epiphytes is characterized by a strain-dependent $\mathrm{H}_{2} \mathrm{O}_{2}$ signature.

Due to their greater mass, the seedlings were the most likely source of the majority of $\mathrm{H}_{2} \mathrm{O}_{2}$ measured during the interaction with epiphytic bacteria of the seed microbiota. Nonetheless,
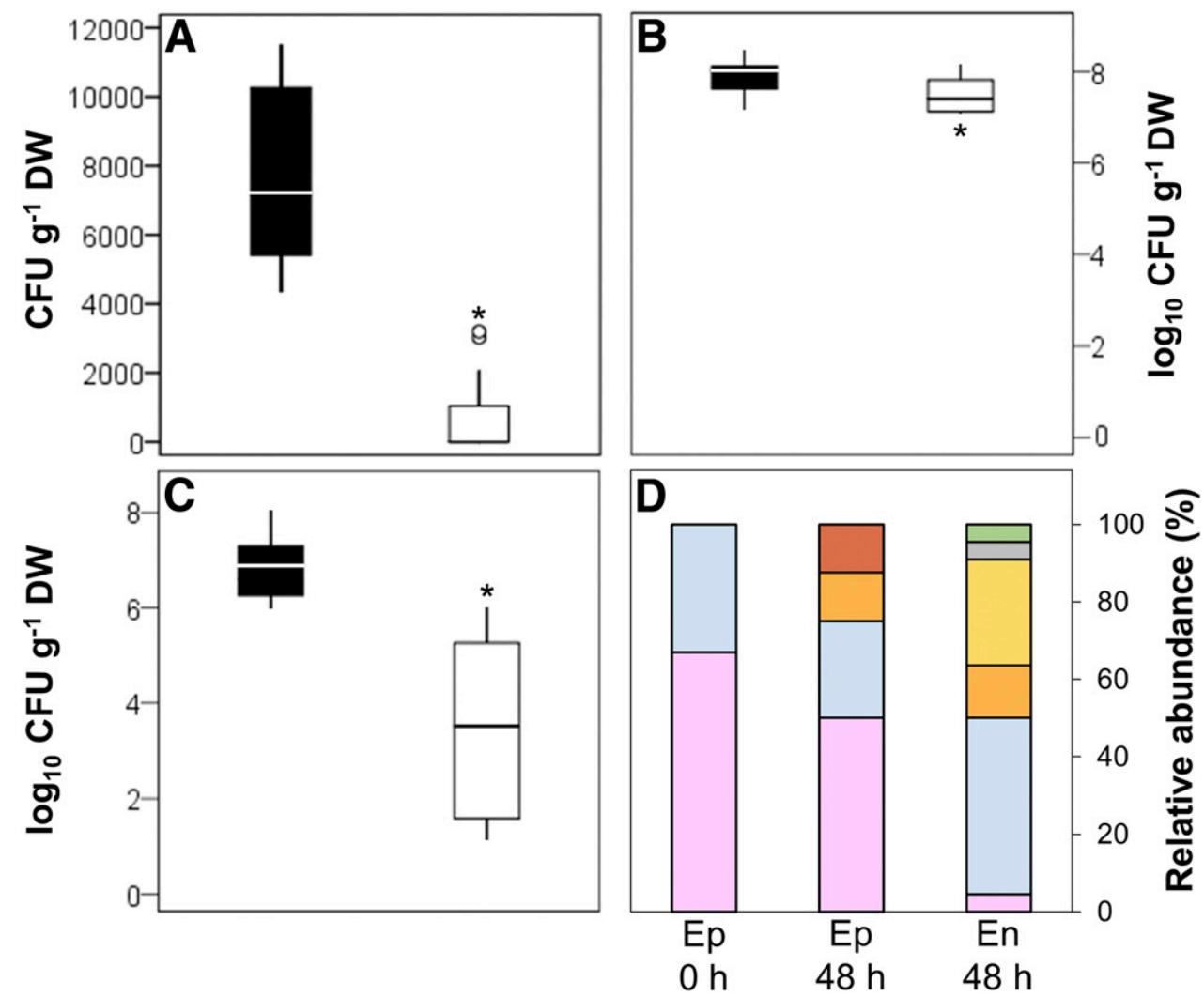

Fig. 2. Effects of hot steam treatment on the microbial load of seeds and seedlings and changes in the composition of culturable bacterial microbiota. A, Epiphytic colony-forming units isolated from the surface of dry seeds. B and $\mathbf{C}$, Epiphytic and endophytic, respectively, colony-forming units isolated from seedlings $48 \mathrm{~h}$ after the onset of imbibition. Black and white refer to control (i.e., untreated samples) and hot steam treatment, respectively. Whiskers indicate minima and maxima, circles indicate outliers, and asterisks denote significant differences between control and hot steam-treated samples $(t$ tests for independent samples, $P<0.05$, four replicates of 10 seeds or seedlings). D, Genera composition of the epiphytic bacterial microbiota isolated from the surface of control dry seeds (Ep 0 h) and seedlings (Ep $48 \mathrm{~h}$ ), and of bacterial endophytes isolated from the endosphere of control seedlings (En $48 \mathrm{~h})$. The genera are shown as follows: Bacillus = yellow, Kosakonia $=$ green, Paenibacillus $=$ orange, Pantoea $=$ pink, Pseudomonas $=$ light blue, Rhodococcus $=$ dark red, and Stenotrophomonas $=$ gray. 
some of these bacteria produced $\mathrm{H}_{2} \mathrm{O}_{2}$ also as pure culture. Particularly, P. agglomerans NT0-7 and NT0-11 produced the most $\mathrm{H}_{2} \mathrm{O}_{2}$ among all strains and about 8.4-fold more than the P. eucalypti NT0-3 and NT0-4 and Pseudomonas oryzihabitans NT0-6 (Fig. 3E). Within genus Pseudomonas, both Pseudomonas fluorescens NT0-2 and NT0-8 produced $\mathrm{H}_{2} \mathrm{O}_{2}$ below the limit of detection, whereas Pseudomonas oryzihabitans NT0-1 generated about 3.2-fold more $\mathrm{H}_{2} \mathrm{O}_{2}$ than strains of Pseudomonas oryzihabitans NT0-6 (Fig. 3E). Regarding $\mathrm{H}_{2} \mathrm{O}_{2}$ breakdown, Pseudomonas fluorescens NT0-2 and NT0-8 had the highest levels of catalase activity among all strains, which may have contributed to the lowest $\mathrm{H}_{2} \mathrm{O}_{2}$ levels $1 \mathrm{~h}$ after combining with seedlings (Fig. 3). Finally, Pseudomonas oryzihabitans NT0-1 and NT0-6 resulted in lowered $\mathrm{H}_{2} \mathrm{O}_{2}$ levels $1.5 \mathrm{~h}$ after seedling inoculation relative to control seedlings (Fig. 3D). These isolates had an intermediate catalase activity (Fig. 3E). Overall, $\mathrm{H}_{2} \mathrm{O}_{2}$ metabolism of tested seed epiphytes clearly differed between species. Additionally, decreased $\mathrm{H}_{2} \mathrm{O}_{2}$ levels in inoculated seedlings agreed with higher catalase activities of the bacterial strains used for inoculation.

\section{High catalase activities of seedling endophytes.}

All endophytic isolates of seedlings showed the ability to decompose $\mathrm{H}_{2} \mathrm{O}_{2}$ via catalase activity in the microkatal range. One third of the Pseudomonas isolates from the seedling endosphere displayed the highest catalase activities (Fig. 4). Differently, the lowest catalase activities (around 4.8-fold lower than those of Pseudomonas isolates NT48-18, NT48-12, and NT48-15) were

Table 1. Molecular identification of bacterial epiphytic and endophytic isolates from bread wheat seeds and seedlings

\begin{tabular}{|c|c|c|c|c|c|c|c|}
\hline \multirow[b]{2}{*}{ Isolate ID } & \multirow[b]{2}{*}{ Origin $^{b}$} & \multirow[b]{2}{*}{ Stage } & \multirow[b]{2}{*}{$\begin{array}{l}\text { 16S rRNA gene } \\
\text { (RDP classifier) }\end{array}$} & \multicolumn{3}{|c|}{ gyrB (NCBI BLASTN) } & \multirow[b]{2}{*}{ RFLP group } \\
\hline & & & & $\begin{array}{l}\text { Closest identified relative } \\
\text { (GenBank hit) }\end{array}$ & Accession & $\begin{array}{c}\text { Sequence } \\
\text { identity }(\%)\end{array}$ & \\
\hline NT0-1 & s. s. & Dry seed & Pseudomonas sp. & Pseudomonas oryzihabitans BCRC 16007 & AB176836.1 & 99 & A \\
\hline NT0-2 & s. s. & Dry seed & Pseudomonas sp. & Pseudomonas fluorescens $89 \mathrm{~F} 1$ & KX696674.1 & 97 & $\mathrm{~B}$ \\
\hline NT0-3 & s. s. & Dry seed & Pantoea sp. & Pantoea eucalypti & EF988762.1 & 98 & $\mathrm{C}$ \\
\hline NT0-4 & s. s. & Dry seed & Pantoea sp. & Pantoea eucalypti & EF988762.1 & 98 & $\mathrm{C}$ \\
\hline NT0-5 & s. s. & Dry seed & Pantoea sp. & Pantoea agglomerans CFSAN047153 & CP034469.1 & 99 & $\mathrm{D}$ \\
\hline NT0-6 & s. s. & Dry seed & Pseudomonas sp. & Pseudomonas oryzihabitans MS8 & CP022198.1 & 100 & A \\
\hline NT0-7 & s. s. & Dry seed & Pantoea sp. & Pantoea agglomerans CFSAN047153 & СР034469.1 & 99 & $\mathrm{D}$ \\
\hline NT0-8 & s. s. & Dry seed & Pseudomonas sp. & Pseudomonas fluorescens LBUM570 & MG491882.1 & 97 & $\mathrm{E}$ \\
\hline NT0-9 & s. s. & Dry seed & Pantoea sp. & Pantoea agglomerans CFSAN047153 & CP034469.1 & 99 & $\mathrm{D}$ \\
\hline NT0-10 & s. s. & Dry seed & Enterobacteriaceae bacterium & Pantoea agglomerans CFSAN047153 & CP034469.1 & 100 & $\mathrm{D}$ \\
\hline NT0-11 & s. s. & Dry seed & Pantoea sp. & Pantoea agglomerans CFSAN047153 & CP034469.1 & 100 & $\mathrm{D}$ \\
\hline NT0-12 & s. s. & Dry seed & Pantoea sp. & Pantoea agglomerans CFSAN047153 & CP034469.1 & 100 & $\mathrm{D}$ \\
\hline NT0-13 & s. s. & Dry seed & Pantoea sp. & Pantoea agglomerans CFSAN047153 & CP034469.1 & 99 & $\mathrm{D}$ \\
\hline NT0-14 & s. s. & Dry seed & Pseudomonas sp. & Pseudomonas oryzihabitans MS8 & CP022198.1 & 100 & A \\
\hline NT0-15 & s. s. & Dry seed & Pantoea sp. & Pantoea agglomerans CFSAN047153 & СР034469.1 & 99 & $\mathrm{D}$ \\
\hline NT0-16 & s. s. & Dry seed & Enterobacteriaceae bacterium & Pantoea agglomerans CFSAN047153 & CP034469.1 & 99 & $\mathrm{D}$ \\
\hline NT48-1 & e. & Seedling & Bacillus sp. & n.d. & n.d. & n.d. & n.d. \\
\hline NT48-2 & e. & Seedling & Bacillus sp. & n.d. & n.d. & n.d. & n.d. \\
\hline NT48-3 & e. & Seedling & Paenibacillus sp. & n.d. & n.d. & n.d. & n.d. \\
\hline NT48-4 & e. & Seedling & Bacillus sp. & n.d. & n.d. & n.d. & n.d. \\
\hline NT48-5 & e. & Seedling & Bacillus sp. & n.d. & n.d. & n.d. & n.d. \\
\hline NT48-6 & e. & Seedling & Paenibacillus sp. & n.d. & n.d. & n.d. & n.d. \\
\hline NT48-7 & e. & Seedling & Pseudomonas sp. & n.d. & n.d. & n.d. & n.d. \\
\hline NT48-8 & e. & Seedling & Pseudomonas sp. & n.d. & n.d. & n.d. & n.d. \\
\hline NT48-9 & e. & Seedling & Pseudomonas sp. & n.d. & n.d. & n.d. & n.d. \\
\hline NT48-10 & e. & Seedling & Pseudomonas sp. & n.d. & n.d. & n.d. & n.d. \\
\hline NT48-11 & e. & Seedling & Pseudomonas sp. & n.d. & n.d. & n.d. & n.d. \\
\hline NT48-12 & e. & Seedling & Pseudomonas sp. & n.d. & n.d. & n.d. & n.d. \\
\hline NT48-13 & e. & Seedling & Stenotrophomonas sp. & n.d. & n.d. & n.d. & n.d. \\
\hline NT48-14 & e. & Seedling & Paenibacillus sp. & n.d. & n.d. & n.d. & n.d. \\
\hline NT48-15 & e. & Seedling & Pseudomonas sp. & n.d. & n.d. & n.d. & n.d. \\
\hline NT48-16 & e. & Seedling & Pseudomonas sp. & n.d. & n.d. & n.d. & n.d. \\
\hline NT48-17 & e. & Seedling & Bacillus sp. & n.d. & n.d. & n.d. & n.d. \\
\hline NT48-18 & e. & Seedling & Pseudomonas sp. & n.d. & n.d. & n.d. & n.d. \\
\hline NT48-19 & e. & Seedling & Kosakonia sp. & n.d. & n.d. & n.d. & n.d. \\
\hline NT48-20 & e. & Seedling & Bacillus sp. & n.d. & n.d. & n.d. & n.d. \\
\hline NT48-21 & e. & Seedling & Pantoea sp. & n.d. & n.d. & n.d. & n.d. \\
\hline NT48-22 & sl. s. & Seedling & Pantoea sp. & n.d. & n.d. & n.d. & n.d. \\
\hline NT48-23 & sl. s. & Seedling & Pseudomonas sp. & n.d. & n.d. & n.d. & n.d. \\
\hline NT48-24 & sl. s. & Seedling & Paenibacillus sp. & n.d. & n.d. & n.d. & n.d. \\
\hline NT48-25 & sl. s. & Seedling & Pseudomonas sp. & n.d. & n.d. & n.d. & n.d. \\
\hline NT48-26 & sl. s. & Seedling & Pantoea sp. & n.d. & n.d. & n.d. & n.d. \\
\hline NT48-27 & sl. s. & Seedling & Pantoea sp. & n.d. & n.d. & n.d. & n.d. \\
\hline NT48-28 & sl. s. & Seedling & Rhodococcus sp. & n.d. & n.d. & n.d. & n.d. \\
\hline NT48-29 & sl. s. & Seedling & Pantoea sp. & n.d. & n.d. & n.d. & n.d. \\
\hline
\end{tabular}

${ }^{a}$ Isolates were obtained from nontreated seeds (NT) in the dry state (NT0) and from seedlings 48 h after the onset of imbibition (NT48). All isolates were characterized by $16 \mathrm{~S}$ ribosomal (r)RNA gene sequencing and were assigned to genera according to the Ribosome Database Project (RDP) classifier. Epiphytic isolates from the surface of dry control seeds were further molecularly identified based on ribotypes and gyrase $B$ ( $g y r B$ ) sequencing. Ribotypes were revealed by restriction fragment length polymorphism (RFLP) of the intergenic spacer region (IGS), and only isolates resulting in values of gyr $B$ sequence similarity of at least $97 \%$ are listed. Pantoea sp. isolates were assigned to IGS groups based on polymorphisms revealed by IGS digestion with $A l u I$ and HhaI. For Pseudomonas sp. isolates the restriction enzyme RsaI was also included.

b s. s. = seed surface, e. = endosphere, sl. s. = seedling surface. 
measured in all isolates from the seedling surface assigned to genus Pantoea and in the seedling epiphytic isolate of genus Rhodococcus (Fig. 4). High catalase activities appeared also in other endophytic isolates assigned to genera Pseudomonas and Bacillus, which were among the most represented cultured endophytes (Fig. 2D and 4). Catalase activities of the other bacteria, including isolates of genera Paenibacillus, Stenotrophomonas, and Kosakonia, had intermediate catalase activities between those of Pseudomonas endophytes and Pantoea and Rhodococcus epiphytes, without differing significantly (Fig. 4). Ultimately, among seedling epiphytic isolates, isolates of genera Pantoea and Rhodococcus revealed lower catalase activities in comparison with isolates of genera Pseudomonas and Bacillus. (Fig. 4).

\section{DISCUSSION}

Physical sanitation treatments based on hot steam have been optimized to eradicate seed-born pathogens from crops for the
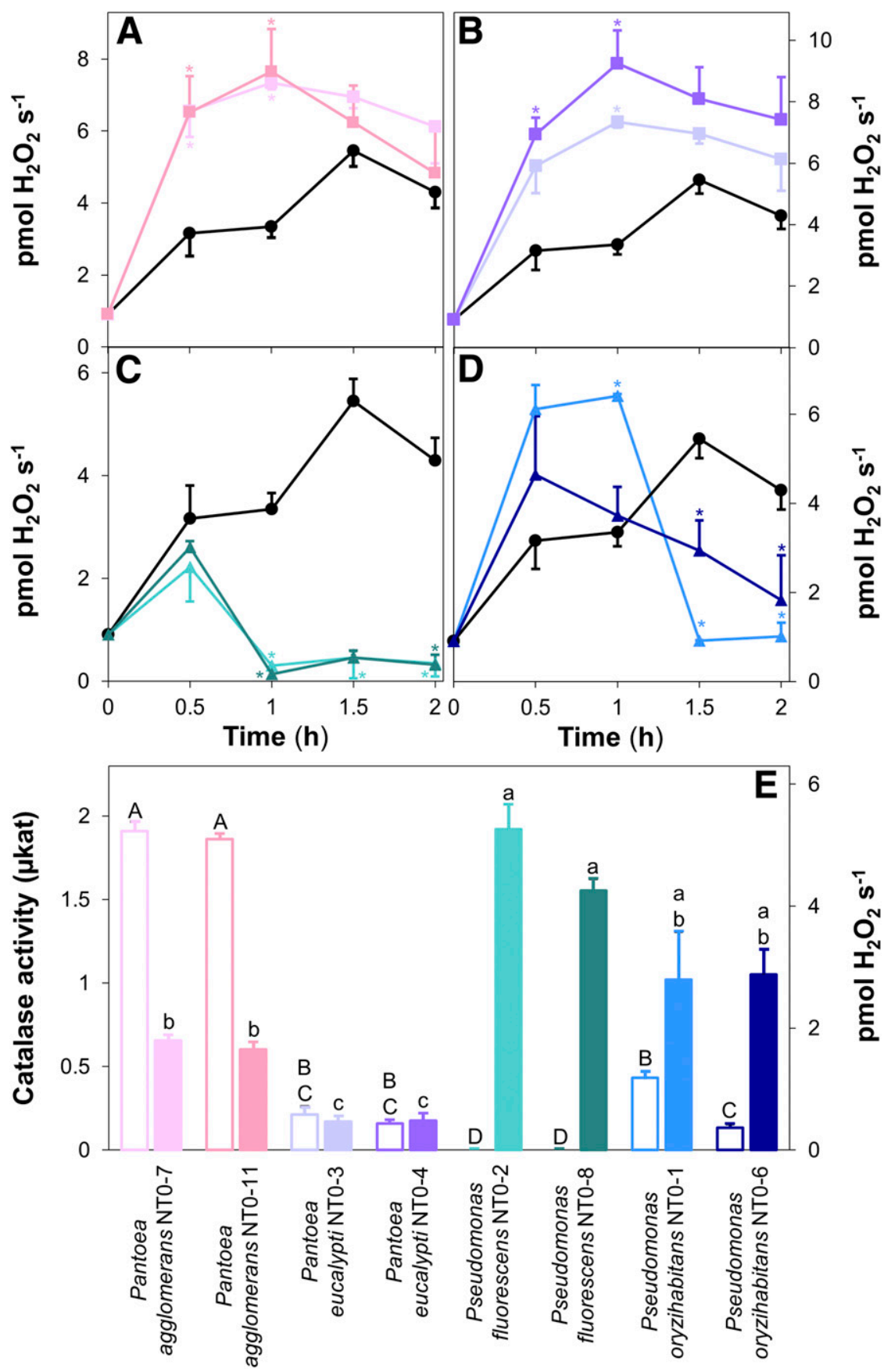

Fig. 3. Hydrogen peroxide $\left(\mathrm{H}_{2} \mathrm{O}_{2}\right)$-mediated interactions between wheat seedlings and epiphytic bacteria isolated from dry seeds. A, Seedlings from hot steam-treated seeds (four replicates of 10 seedlings), $48 \mathrm{~h}$ after the onset of imbibition, were inoculated by incubation with pure cultures of two strains of Pantoea agglomerans (NT0-7, light pink squares; NT0-11, dark pink squares), B, two strains of Pantoea eucalypti (NT0-3, light purple squares; NT0-4, dark purple squares), C, two strains of Pseudomonas fluorescens (NT0-2, light green triangles; NT0-8, dark green triangles), and D, two strains of Pseudomonas oryzihabitans (NT0-1, light blue triangles; NT0-6, dark blue triangles). Seedlings were also incubated in sterile bacterial medium to be used as a control (black circles). Asterisks denote significant differences $(P<0.05)$ between control and inoculated seedlings at individual timepoints; data shows means of $n=9 \pm$ standard error (SE) for seedlings only and $n=3$ to $4 \pm$ SE for seedlings inoculated with each strain. E, Average $\mathrm{H}_{2} \mathrm{O}_{2}$ production (open bars) and catalase activity (closed bars) of strains in pure culture. Different upper and lower case letters denote significant differences of $\mathrm{H}_{2} \mathrm{O}_{2}$ production and catalase activity, respectively $(n=3$ to $4 \pm \mathrm{SE})$. All data were tested for significance by one-way analyses of variance followed by post hoc Tukey's honest significant difference test. 
benefit of agricultural productivity (Baker 1969; Forsberg et al. 2002, 2005; Groot et al. 2006; Koch et al. 2010; Watts et al. 1993). Microorganisms tend to have lower tolerance to hot steam than seeds, resulting in seed sanitation without compromising seed vigor and viability (Groot et al. 2006). Previously, we found that the hot steam-treated bread wheat seeds used in this study germinate faster and also possess an advanced germination-associated metabolism (Gerna et al. 2018). Here, the hot steam treatment was shown to also entail seed-surface disinfection (Fig. 2A), which was useful to investigate the communication between seeds and their inborn bacteria during germination and early seedling growth. Notably, $48 \mathrm{~h}$ after the onset of imbibition, the number of colonyforming units exponentially increased (Fig. 2B and C). This result agrees with other studies indicating that bacteria of the seed microbiota, especially endophytes, proliferate during and after germination (Barret et al. 2015; Nelson 2018; TorresCortés et al. 2018).

Separately isolating endophytes and epiphytes from seeds and seedlings germinated under sterile conditions was useful to analyze the redistribution dynamics of surface-inhabiting and endosphere-inhabiting microbiota. Conversions from endophytic to epiphytic lifestyles and vice versa are expected to occur during germination and seedling growth, making the definition of endophyte and epiphytes quite transitory (Barret et al. 2016; Nelson 2018).
Upon completion of seed germination, new bacterial genera were detected among the epiphytes. Genus Rhodococcus, mostly including nonsporulating species sensitive to desiccation (Elsayed et al. 2017), was not represented among epiphytes of dry seeds but was later identified on the seedling surface. This finding suggests that the Rhodococcus sp. isolates presumably originated from the seed endosphere, where they could have resided in local pockets of hydration found in dry seeds (Manz et al. 2005; Rathjen et al. 2009), then becoming epiphytic during germination and early seedling growth. Eventually, bacterial epiphytes unculturable from dry seeds were apparently reactivated during seed imbibition and germination, enabling their isolation from seedlings. This could be the case for the mostly endospore-forming genus Paenibacillus (Grady et al. 2016). The other seedling epiphytic genera Pantoea and Pseudomonas have been recently described as copiotrophic taxa, which become particularly abundant during seedling growth (Torres-Cortés et al. 2018). At this stage, storage reserves are remobilized to support the heterotrophic seedling, also increasing nutrient availability to its microbiota (Barret et al. 2015; Gerna et al. 2017; Ho et al. 2017; Nonogaki et al. 2010).

In this study, bacterial endophytes isolated from seedlings were assigned to genera commonly described in the seed endosphere microbiota of different plant species (Compant et al. 2011; Hardoim et al. 2015; Rahman et al. 2018; Truyens

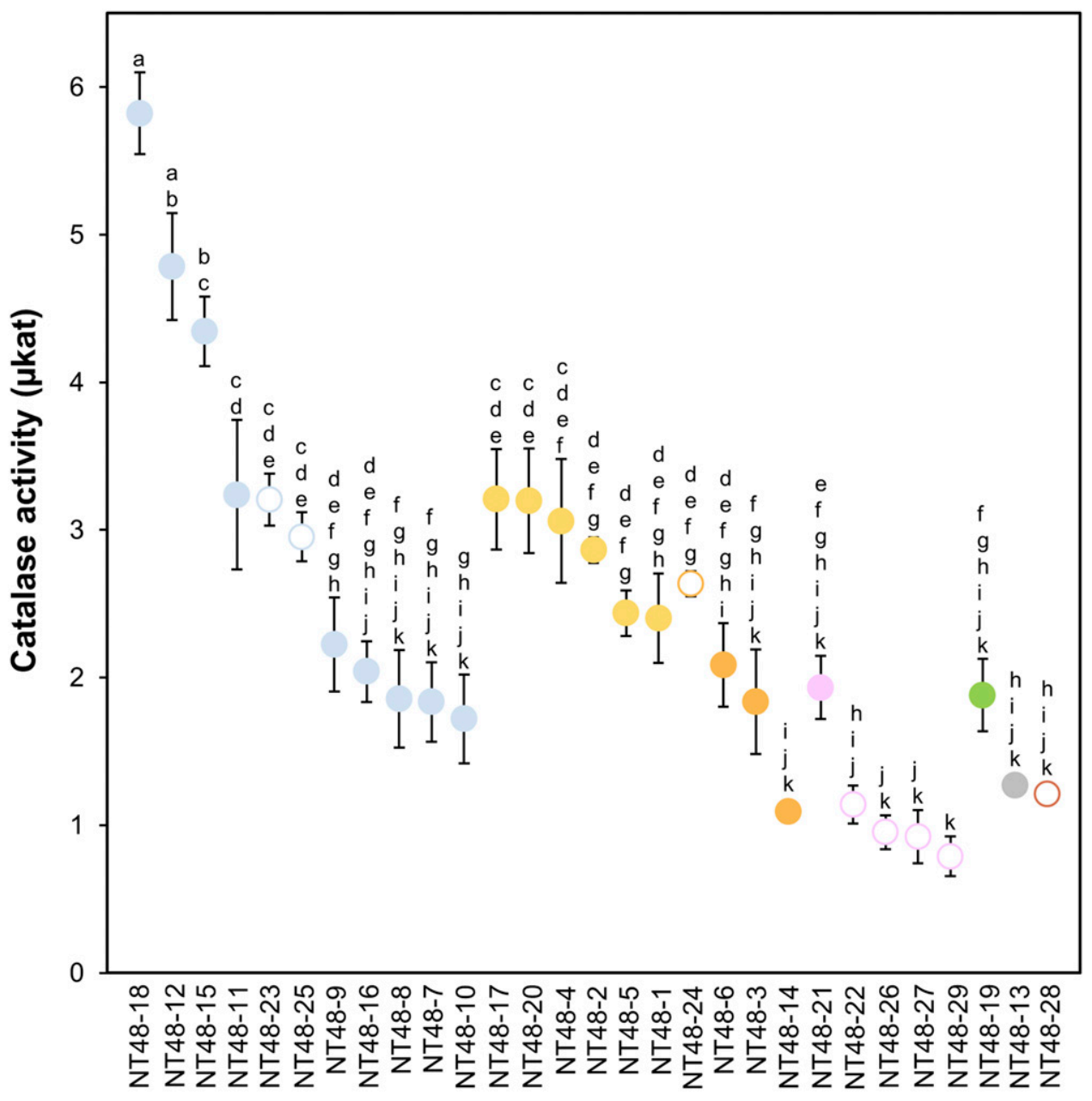

Fig. 4. Catalase activity of individual endophytic and epiphytic isolates from wheat seedlings identified by $16 \mathrm{~S}$ ribosomal RNA gene sequencing. Endophytic (closed circles) and epiphytic (open circles) isolates were obtained from seedlings $48 \mathrm{~h}$ after the onset of imbibition of control untreated seeds. The genera are shown as follows: Bacillus = yellow, Kosakonia $=$ green, Paenibacillus $=$ orange, Pantoea $=$ pink, Pseudomonas $=$ light blue, Rhodococcus $=$ dark red, and Stenotrophomonas $=$ gray. Data are means \pm standard error (three colonies for each isolate), and those labeled with the same letter do not differ significantly (nonparametric Kruskal-Wallis test by ranks, followed by post hoc Tukey's honest significant difference test, $\alpha=0.05$ ). 
et al. 2015; Walitang et al. 2017). Genus Pantoea is extremely versatile in terms of ecological niches, hosts, and lifestyles ranging from parasitism to mutualism, including promotion of plant growth (Walterson and Stavrinides 2015). Notably, the species $P$. agglomerans is a common epiphyte in several crops and a dominant species of the epiphytic microbiota of dry wheat seeds (Dutkiewicz et al. 2016; Walterson and Stavrinides 2015). High metabolic versatility and adaptation to multiple host niches also characterize genus Stenotrophomonas, comprising common endophytes and some strains applied as plant growth-promoting rhizobacteria to improve wheat stress resistance (Ryan et al. 2009; Singh and Jha 2017). Finally, seedlings from hot steam-treated seeds hosted fewer endophytes compared with untreated controls (Fig. 2A and C). Therefore, it can be inferred that the hot steam treatment presumably also contributed to decreasing endophytic microbial load of dry seeds, from which no endophytes could be cultured.

Hot steam-treated seeds produced lower amounts of $\mathrm{H}_{2} \mathrm{O}_{2}$ compared with control seeds (Fig. 1B), showing that a higher microbial load of the natural wheat seed microbiota is associated with increased $\mathrm{H}_{2} \mathrm{O}_{2}$ production and thus validating our hypothesis that seed microbiota induce $\mathrm{H}_{2} \mathrm{O}_{2}$ production during seed germination. Interestingly, seedlings from control seeds produced extracellular ROS predominantly from their roots but not from the shoot (Fig. 1D). This evidence indicates that the seedling microbiota eliciting the oxidative burst were most active in roots and agrees with data by Rahman et al. (2018), who found that seed endophytic species of surface-sterilized barley seeds colonized roots during seedling growth. Intense ROS staining was particularly visible in the root elongation zone, supporting previous findings that extracellular ROS production by the plant has a well-characterized function in cell-wall remodeling for growth (Camejo et al. 2016; Foreman et al. 2003; Kranner et al. 2010b; Müller et al. 2009; Singh and Jha 2017). Besides its key signaling role in seed germination and seedling growth, $\mathrm{H}_{2} \mathrm{O}_{2}$ also mediates plant interaction with bacteria, possibly including those between seeds and endophytes (Grant and Loake 2000; Hammond-Kosack and Jones 1996; Kranner et al. 2010a; Levine et al. 1994; Wojtyla et al. 2016). Initially, plant-microbe interaction induces an oxidative burst, which includes a rapid release of $\mathrm{H}_{2} \mathrm{O}_{2}$ by plant cells (Lamb and Dixon 1997; Wojtaszek 1997). Therefore, we quantified extracellular $\mathrm{H}_{2} \mathrm{O}_{2}$ production in untreated control and hot steam-treated seeds during and after germination. Additionally, to simulate initial interactions with epiphytes, seedlings from hot steam-treated seeds were exposed to strains isolated as epiphytes from dry control seeds. Notably, seedlings responded differently upon exposure to Pantoea and Pseudomonas strains from dry seeds (Fig. 3A to D; Table 1). An $\mathrm{H}_{2} \mathrm{O}_{2}$ burst was detected after $0.5 \mathrm{~h}$ in response to $P$. agglomerans NT0-7 and NT0-11 and P. eucalypti NT0-3 and NT0-4 (Fig. 3A and $\mathrm{B}$ ), supporting results on wheat cell cultures in which elevated $\mathrm{H}_{2} \mathrm{O}_{2}$ production by plant cells was triggered by $P$. agglomerans exopolysaccharides released into the growing medium (Ortmann and Moerschbacher 2006; Ortmann et al. 2006). However, as cultures of $P$. agglomerans NT0-7 and NT0-11 themselves produced more $\mathrm{H}_{2} \mathrm{O}_{2}$ than $P$. eucalypti NT0-3 and NT0-4, $\mathrm{H}_{2} \mathrm{O}_{2}$ produced by the bacteria may have contributed to measurements after pure cultures were mixed with seedlings (Fig. 3D). Differently, decreased $\mathrm{H}_{2} \mathrm{O}_{2}$ levels were revealed after inoculation of seedlings with Pseudomonas seed epiphytic strains, pointing to a breakdown of seedlingreleased $\mathrm{H}_{2} \mathrm{O}_{2}$ by these epiphytes (Fig. 3C and D). This finding is consistent with high catalase activities and undetectable (Pseudomonas fluorescens NT0-2 and NT0-8) or low (Pseudomonas oryzihabitans $\mathrm{NT} 0-1$ and $\mathrm{NT} 0-6) \mathrm{H}_{2} \mathrm{O}_{2}$ production in pure cultures of both Pseudomonas species (Fig. 3E). Other studies report on isolates of Pseudomonas oryzihabitans as seed-borne endophytes with catalase activity and beneficial effects on plant growth (Bhagat et al. 2016; Cottyn et al. 2009; Hardoim et al. 2012; Kodama et al. 1985). Furthermore, inducible catalase activity is also a distinctive trait of some Pseudomonas fluorescens strains (Alhasawi et al. 2015; Rodríguez-Bravo and Pionetti 1981).

In summary, strains of genus Pantoea triggered an early $\mathrm{H}_{2} \mathrm{O}_{2}$ burst whereas strains of genus Pseudomonas decomposed plant-generated $\mathrm{H}_{2} \mathrm{O}_{2}$, thus showing that the extracellular redox environment of the seedling can be modulated by bacterial epiphytes. Since a greater native microbial load was associated with more $\mathrm{H}_{2} \mathrm{O}_{2}$ production during germination (Fig. 1B), $\mathrm{H}_{2} \mathrm{O}_{2}$-elicitaing strains, such as those of Pantoea spp., contributed more to the net extracellular $\mathrm{H}_{2} \mathrm{O}_{2}$ levels (Fig. 3A and B). Scavenging of $\mathrm{H}_{2} \mathrm{O}_{2}$ by, for example, Pseudomonas spp. (Fig. 4) would have been more influential in the endosphere, in which isolates of this genus were more abundant (Fig. 2D).

Several genomic and metagenomic studies on bacterial endophytes identified diverse gene clusters of ROS-processing enzymes, suggesting their relevance to endophytic colonization of plants (Alquéres et al. 2013; Araújo et al. 2015; Mitter et al. 2013; Sessitsch et al. 2012; Sheibani-Tezerji et al. 2015; Taghavi et al. 2010). Particularly, catalases are among the bestcharacterized and largest group of $\mathrm{H}_{2} \mathrm{O}_{2}$-degrading enzymes that maintain redox poise in eubacteria (Imlay 2015; van der Heijden et al. 2016; Zamocky et al. 2008) and are recurrently found in seed endophytic microbiomes (Hardoim et al. 2015). However, to date, very few studies have actually quantified catalase activity of endophytes. Much more commonly, isolates are simply reported as "catalase positive" or "catalase negative" (Naveed et al. 2014; Okunishi et al. 2005; Sheibani-Tezerji et al. 2015; Walitang et al. 2017). In this study, we provide physiological support to the importance of ROS-processing systems of seed endophytic bacteria through spectrophotometric quantification of catalase activity. Notably, many isolates assigned to genera Pseudomonas and Bacillus were identified as most abundant seedling endophytes and displayed higher catalase activity compared with other culturable isolates of less abundant genera (Fig. 4). Some epiphytic isolates of genera Pseudomonas and Bacillus had relatively high catalase activities, which may provide versatility to also live as an endophyte.

In conclusion, seed germination and seedling growth are highly dynamic processes entailing morphological, physiological, and redox changes in both endosphere and surface tissues. This requires physiological plasticity of the seed microbiota, including a capability to tolerate and modulate $\mathrm{H}_{2} \mathrm{O}_{2}$ production by the seed and seedling. Therefore, we conclude that rapid $\mathrm{H}_{2} \mathrm{O}_{2}$ metabolism by catalases is a key attribute of seed endophytes.

\section{MATERIALS AND METHODS}

\section{Seed treatment, germination, and staining of ROS.}

Bread wheat seeds (Triticum aestivum L. 'Rebelde') produced in the 2013 to 2014 growing season were provided by the Council for Agricultural Research and Economics (CREA) of Sant'Angelo Lodigiano (Italy). Seeds were harvested at maturity (growth stage 90 [Zadoks et al. 1974]) and were pooled in a 2-kg lot, of which $1 \mathrm{~kg}$ was left untreated (control) and $1 \mathrm{~kg}$ was exposed to hot steam treatment, using an industrial method (BioFlash, Hoopman Equipment \& Engineering, Aalten, The Netherlands). This treatment was developed as a physical seed sanitation procedure against seed-borne pathogens, using a 
controlled flux of hot steam in a chamber containing the seeds. Within $18 \mathrm{~s}$, air temperature was increased to $65.0 \pm 0.3^{\circ} \mathrm{C}$ (standard deviation [SD]) and was maintained for $1 \mathrm{~s}$ (flash duration), after which the steam flux was interrupted, allowing cooling to $18.5 \pm 0.2^{\circ} \mathrm{C}$ (SD) within $85 \mathrm{~s}$. This cycle was repeated twice, for an overall duration of 4 min (Fig. 1A). After the treatment, seeds were re-dried at ambient conditions, were then stored at $4{ }^{\circ} \mathrm{C}$ in a sealed box over silica gel, and were analyzed within 32 months. In this report, seeds treated with BioFlash and untreated seeds are termed hot steam-treated and control, respectively.

For germination under sterile conditions, seeds were sown in 90-mm Petri dishes on two layers of filter paper (Whatman 1; GE Healthcare, Little Chalfont, U.K.) imbibed with $3 \mathrm{ml}$ of autoclaved distilled $\mathrm{H}_{2} \mathrm{O}\left(\mathrm{dH}_{2} \mathrm{O}\right)$ at $20^{\circ} \mathrm{C}$ in the dark. Total germination was scored at regular intervals over $48 \mathrm{~h}$, which was the time required by all viable seeds to complete germination (Supplementary Fig. S1). A seed was scored as germinated once the radicle protruded through the coleorhiza by at least $1 \mathrm{~mm}$.

To stain ROS produced during germination and early seedling growth, control and hot steam-treated seeds (four replicates of 10 seeds each for both treatments) were germinated for 8 and $48 \mathrm{~h}$ prior to incubation in a $5 \mathrm{mM}$ solution of NBT in $20 \mathrm{mM}$ Tris- $\mathrm{HCl}$ buffer $(\mathrm{pH} 7.40)$ at room temperature for $30 \mathrm{~min}$. After thoroughly rinsing with $\mathrm{dH}_{2} \mathrm{O}$, seeds were analyzed with an Olympus KL 1500 LC (Olympus Corporation, Tokyo) stereomicroscope and snapshots captured with the software Intervideo WinDVR v3.0. Insoluble purple formazan precipitates were indicative of ROS production.

\section{Isolation of epiphytes and endophytes from seeds and seedlings.}

Seed epiphytes were isolated by washing the surface of dry seeds (four replicates of 10 seeds) with $700 \mu$ l of sterilized $0.9 \%$ (wt/vol) $\mathrm{NaCl}\left(780 \mathrm{rpm}, 15 \mathrm{~min}, 4^{\circ} \mathrm{C}\right)$, using a compact digital microplate shaker (Thermo Fisher Scientific, Waltham, MA, U.S.A.). Unless specified differently, all chemicals were purchased from Sigma Aldrich (St. Louis).

To quantify epiphytic colony-forming units of control and hot steam-treated seeds, $10-\mu \mathrm{l}$ aliquots of the washing suspensions were 10 -fold serially diluted with sterilized $0.9 \%$ (wt/vol) $\mathrm{NaCl}$ in sterile 96-well Brand plates-pureGrade $\mathrm{S}$ (Brand $\mathrm{GmbH} \& \mathrm{Co} \mathrm{KG}$, Wertheim, Germany) and were plated on $10 \%$ (wt/wt) tryptic soy agar (TSA) (VWR International, Radnor, PA, U.S.A.) prior to incubation $\left(28^{\circ} \mathrm{C}, 24\right.$ to $\left.48 \mathrm{~h}\right)$. Sterilized $0.9 \%$ (wt/vol) $\mathrm{NaCl}$ was included as a blank and nine technical replicates for each biological replicate $(n=4)$, and the two treatments were measured. The optical density of the seedwashing suspensions were spectrophotometrically quantified at a wavelength $(\lambda)$ of $600 \mathrm{~nm}\left(\mathrm{OD}_{600}\right)$, using a microplate reader (Synergy-HTX multimode reader; BioTek Instruments, Inc., Winooski, VT, U.S.A.). Following a culture-dependent approach, $15 \mu$ l of the seed-washing suspensions ( $n=4,10$ control seeds each) were streaked on $10 \%$ (wt/wt) TSA and were incubated at $28^{\circ} \mathrm{C}$ for 24 to $48 \mathrm{~h}$. Based on phenotypic differences, single colonies $(n=18)$ were selected from all four Petri dishes, were individually loop-inoculated in 100-ml Erlenmeyer flasks containing $10 \mathrm{ml}$ of $10 \%$ (wt/vol) TSB (Corning Inc., Corning, NY, U.S.A.) and were grown overnight $\left(28^{\circ} \mathrm{C}\right.$, $180 \mathrm{rpm}$ ) prior to storage at $-80^{\circ} \mathrm{C}$ as glycerol stocks. Similarly, seedling epiphytes with different morphologies were isolated from the surface of seedlings $48 \mathrm{~h}$ after the onset of imbibition of control and hot steam-treated seeds.

Endophytes were isolated from control and hot steam-treated seeds and corresponding seedlings (four replicates of 10 seeds for both treatments) after chemical surface sterilization. This consisted of sequential exposure of seeds to $70 \%$ ( $\mathrm{vol} / \mathrm{vol})$ ethanol for $3 \mathrm{~min}$ and $2 \%$ ( $\mathrm{vol} / \mathrm{vol}$ ) sodium hypochlorite $(\mathrm{NaOCl})$ for $5 \mathrm{~min}$, followed by three rinsing steps of $1 \mathrm{~min}$ each with autoclaved ultrapure $\mathrm{H}_{2} \mathrm{O}$ (aUPW), as described by Naveed et al. (2014). One blank without seeds was processed to exclude any sources of contamination from solutions and equipment. To check eradication of seed epiphytes, seeds were resuspended in $700 \mu \mathrm{l}$ of sterilized $0.9 \%$ (wt/vol) $\mathrm{NaCl} ; 15 \mu \mathrm{l}$ of all suspensions were plated on $10 \%$ (wt/wt) TSA and were incubated at $28^{\circ} \mathrm{C}$ for 1 week. Immediately after chemical surface sterilization, control and hot steam-treated seeds were germinated for $48 \mathrm{~h}$ under sterile conditions. Thereupon, samples were transferred to autoclaved 5-ml Teflon capsules (Sartorius AG, Göttingen, Germany) and were ground with 1-cm diameter agate beads, using a Mikro-Dismembrator $\mathrm{S}$ (B. Braun Biotech International, Melsungen, Germany) at $3,000 \mathrm{rpm}$ for $30 \mathrm{~s}$. Obtained seedling slurries were collected into 2-ml Eppendorf tubes containing 3-mm diameter autoclaved glass beads (Carl Roth $\mathrm{GmbH} \& \mathrm{Co}$, Karlsruhe, Germany), prior to resuspending $(30 \mathrm{~Hz}, 1 \mathrm{~min})$ in $1.5 \mathrm{ml}$ of sterilized $0.9 \%$ (wt/vol) $\mathrm{NaCl}$ with a Tissue-Lyser (Qiagen, Hilden, Germany). After resuspension, ground homogenized seedlings were decanted for $90 \mathrm{~min}$ and were centrifuged $(450 \times g, 2 \mathrm{~min})$ to obtain clear supernatants. Finally, $900-\mu 1$ aliquots of supernatants were used to quantify endophytic colony-forming units by 10 -fold serial dilutions, as described for seed epiphytes. The approach adopted to isolate individual colonies of seedling endophytes $(n=21)$ was then equivalent to that used for epiphytes. To normalize the colony-forming units to a dry weight (DW) basis, the weights of intact (for epiphytes) and ground (for endophytes) seeds and seedlings were recorded with an analytical balance (XS105, Mettler-Toledo $\mathrm{GmbH}$, Columbus, $\mathrm{OH}$, U.S.A.) after drying at $103^{\circ} \mathrm{C}$ for $17 \mathrm{~h}$.

\section{Quantification of $\mathrm{H}_{2} \mathrm{O}_{2}$ production in seeds, seedlings, and isolated seed epiphytes.}

To quantify the extracellular production of $\mathrm{H}_{2} \mathrm{O}_{2}$ by control and hot steam-treated seeds during germination and early seedling growth, a horseradish peroxidase (HPOX)-coupled fluorimetric assay was developed. Briefly, seeds were incubated for $30 \mathrm{~min}$ in the dark with $950 \mu \mathrm{l}$ of $50 \mathrm{mM}$ Sørensen phosphate buffer ( $\mathrm{pH} 7.40$, hereafter called assay buffer), $40 \mu \mathrm{l}$ of $20 \mathrm{U}$ of HPOX per milliliter, and $10 \mu \mathrm{l}$ of $2 \mathrm{mM}$ AmpliFlu Red (10-acetyl-3,7-dihydroxyphenoxazine) in dimethyl sulphoxide. Reaction mixtures were twofold diluted prior to measuring fluorescence $\left(\lambda_{\text {excitation }}=540 \pm 35 \mathrm{~nm}, \lambda_{\text {emission }}=590 \pm\right.$ $20 \mathrm{~nm}$ ) of resorufin (7-hydroxy-3H-phenoxazin-3-one), the $\mathrm{H}_{2} \mathrm{O}_{2}$-HPOX product generated from AmpliFlu Red, using a microplate reader (Synergy-HTX multimode reader, BioTek Instruments, Inc.). Data were corrected for background fluorescence occurring in the presence of pure assay buffer. Three technical replicates were measured for each biological replicate ( $n=3$, each containing 20 seeds). Seed and seedling $\mathrm{H}_{2} \mathrm{O}_{2}$ contents were calculated from a standard curve of $\mathrm{H}_{2} \mathrm{O}_{2}(0$ to $10 \mu \mathrm{M}$ range), and data were normalized on a time and DW basis, after drying samples at $103^{\circ} \mathrm{C}$ for $17 \mathrm{~h}$. Selected epiphytic bacterial isolates of $P$. agglomerans (strains NT0-7 and NT0-11), P. eucalypti (strains NT0-3 and NT0-4), Pseudomonas fluorescens (strains NT0-2 and NT0-8), and Pseudomonas oryzihabitans (strains NT0-1 and NT0-6), obtained from the surfaces of dry control seeds, were grown by loop-inoculating single colonies (three to four colonies for each isolate) in $10 \%$ (wt/vol) TSB. Following overnight incubation $\left(28^{\circ} \mathrm{C}, 180 \mathrm{rpm}\right)$, the $\mathrm{OD}_{600}$ values of pure cultures were measured spectrophotometrically and were adjusted to 0.4 to obtain uniform populations of bacteria and to normalize the $\mathrm{H}_{2} \mathrm{O}_{2}$ production. This was determined as for seeds, using a reaction mixture of $200 \mu \mathrm{l}$ 
combined with $30 \mu \mathrm{l}$ of each bacterial cultures. After brief vortexing and spinning, the reaction mixtures were incubated for $30 \mathrm{~min}$ in the dark and were then twofold diluted with assay buffer, and the resorufin fluorescence of three technical replicates for each biological replicate ( $n=3$ to 4 ) was measured. As negative controls, individual reactions for each isolate were prepared by mixing $170 \mu \mathrm{l}$ of assay buffer with $30 \mu \mathrm{l}$ of bacterial cells at an $\mathrm{OD}_{600}$ of 0.4 . Finally, blanks containing assay buffer and TSB were included to correct for background fluorescence. Data were expressed as $\mathrm{H}_{2} \mathrm{O}_{2}$ contents per flask of pure bacterial culture and were normalized over time.

\section{Quantification of $\mathrm{H}_{2} \mathrm{O}_{2}$ production by hot steam-treated seedlings exposed to seed epiphytes.}

Hot steam-treated seeds were germinated under sterility for $48 \mathrm{~h}$, prior to inoculation with pure cultures of $P$. agglomerans NT0-7 and NT0-11, P. eucalypti NT0-3 and NT0-4, Pseudomonas fluorescens NT0-2 and NT0-8, and Pseudomonas oryzihabitans NT0-1 and NT0-6, isolated as epiphytes from the surfaces of control seeds. Nongerminated seeds were disregarded, and pools of 10 intact seedlings $(n=4$, for each bacterial strain) were inoculated by incubating in Erlenmeyer flasks containing $20 \mathrm{ml}$ of pure cultures of each bacterial strain at an $\mathrm{OD}_{600}$ of 0.4 , at $20^{\circ} \mathrm{C}$ and $80 \mathrm{rpm}$. As a control, 10 intact seedlings were incubated in sterilized $10 \%$ (wt/vol) TSB without bacteria. At $30 \mathrm{~min}$ intervals, $160-\mu \mathrm{l}$ aliquots were collected from each flask and were mixed with $2 \mu \mathrm{l}$ of $2 \mathrm{mM}$ AmpliFlu Red, $8 \mu \mathrm{l}$ of $20 \mathrm{U}$ of HPOX per milliliter, and $30 \mu \mathrm{l}$ of assay buffer. Additionally, at each 30 -min interval, $\mathrm{OD}_{600}$ values of suspensions from each flask were monitored, thus excluding the potential that the $\mathrm{H}_{2} \mathrm{O}_{2}$ contents were biased by bacterial growth. All seedlings remained visually undamaged throughout the analyses, which were stopped as soon as the suspensions exceeded an average $\mathrm{OD}_{600}$ of 0.45 . Finally, data were expressed as $\mathrm{H}_{2} \mathrm{O}_{2}$ contents per flask of pure bacterial culture.

\section{Determination of catalase activity of isolated seed epiphytes and endophytes.}

Individual isolates from seedlings were loop-inoculated in sterilized $10 \%$ (wt/vol) TSB and were grown overnight under shaking $\left(28^{\circ} \mathrm{C}, 180 \mathrm{rpm}\right)$. Pure cultures $(n=3$ to 4 , for each isolate) were adjusted to an $\mathrm{OD}_{600}$ value of 0.4 , to obtain uniform populations of bacteria. Catalase (EC 1.11.1.6) activity was measured in $150 \mu \mathrm{l}$ of $50 \mathrm{mM}$ Sørensen phosphate buffer

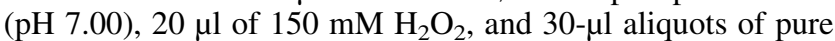
bacterial cultures. As positive control, $0.2 \mathrm{U}$ of catalase from bovine liver were included in each set of measurements. Catalase activity was quantified by following $\mathrm{H}_{2} \mathrm{O}_{2}$ consumption at substrate saturation, indicated by the linear decrease in absorbance at $240 \mathrm{~nm}$ (Bailly and Kranner 2011), and were calculated with a pathlength-corrected molar extinction coefficient $\left(\varepsilon=25.30 \mathrm{mM}^{-1} \mathrm{~cm}^{-1}\right)$, using a microplate reader (SynergyHTX multimode reader, BioTek Instruments, Inc.) and 96-well UV plates (Corning Inc.). Reaction rates were calculated for biological replicates (i.e., cultures from individual colonies of the same isolate, $n=3$ to 4 ), and four technical replicates were averaged.

\section{Molecular identification of seed and seedling epiphytes and endophytes.}

DNA extraction. Individual colonies of epiphytes isolated from control dry seeds $(n=18)$ and of epiphytes $(n=8)$ and endophytes $(n=21)$ from seedlings $48 \mathrm{~h}$ after the onset of imbibition were grown by loop-inoculating in $10 \%$ (wt/vol) TSB. Cultures were incubated for $24 \mathrm{~h}$ at $20^{\circ} \mathrm{C}$ and $180 \mathrm{rpm}$. DNA was extracted using an UltraClean Microbial DNA isolation kit (Mo Bio Laboratories, Inc., Qiagen, Carlsbad, CA,
U.S.A.) and was eluted in $60 \mu \mathrm{l}$ of sterile aUPW, according to manufacturer instructions. Aliquots of $5 \mu \mathrm{l}$ of DNA were visualized by electrophoresis $(100 \mathrm{~V}, 40 \mathrm{~min})$ on $1 \%$ (wt/vol) agarose gel in TBE ( $89 \mathrm{mM}$ Tris, $89 \mathrm{mM}$ borate, $2 \mathrm{mM}$ EDTA, $\mathrm{pH}$ 8.00) buffer (Sambrook and Russel 2001) and were stained with $0.005 \%$ (vol/vol) Midori Green (Bulldog Bio, Inc., Portsmouth, England). DNA concentrations and purities were quantified using a NanoDrop 2000c spectrophotometer (Thermo Fisher Scientific).

16S rRNA gene PCR and sequencing. To group epiphytic and endophytic isolates according to their family and genus, the 16S rRNA gene was PCR-amplified using primers $8 \mathrm{f}$ (5'-AGAGTTTGATCCTGGCTCAG-3') (White et al. 1990) and 1520r (5'-AAGGAGGTGATCCAGCCGCA-3') (Edwards et al. 1989). In a total volume of $50 \mu$ of reaction buffer, the PCR mixture contained $1 \mu \mathrm{l}$ of extracted DNA, $2.5 \mathrm{mM} \mathrm{MgCl}_{2}$, $0.15 \mu \mathrm{M}$ of each primer, $0.2 \mathrm{mM}$ of each deoxynucleoside triphosphate, and 2.5 U of FIREPol DNA polymerase (Solis BioDyne, Tartu, Estonia). PCR cycling conditions included 5 min of denaturation at $96^{\circ} \mathrm{C}$, followed by 30 cycles consisting of denaturation for $30 \mathrm{~s}$ at $90^{\circ} \mathrm{C}$, primer annealing for $1 \mathrm{~min}$ at $52^{\circ} \mathrm{C}$, and polymerization for $2 \mathrm{~min}$ at $72^{\circ} \mathrm{C}$, with a final extension of $10 \mathrm{~min}$ at $72^{\circ} \mathrm{C}$. The quality of the PCR products was assessed by gel electrophoresis, using the same conditions reported for genomic DNA. Isolates were characterized by partially sequencing their 16S rRNA genes with the Sanger method (LCG Genomics $\mathrm{GmbH}$, Berlin) and primers 8f and 1492r (5'-TACGGYT ACCTTGTTACGACTT-3') (Lane 1991). Retrieved sequences were visualized with the sequence alignment editor package BioEdit (Ibis Biosciences, Carlsbad, CA, U.S.A.), were quality filtered, and were trimmed. Finally, Ribosome Database Project (RDP) Classifier and RDP Sequence Match were used to identify epiphytic and endophytic isolates (Wang et al. 2007).

Analysis of the $16 S-23 S$ IGS region and gyraseB gene PCR and sequencing of seed epiphytes. To distinguish closely related epiphytic isolates of dry seeds, the IGS region of the $16 \mathrm{~S}-23 \mathrm{~S}$ rDNA operon was amplified by PCR using primers $\mathrm{pHr}\left(5^{\prime}-\right.$ TGCGGCTGGATCACCTCCTT-3') and P23SR01 (5'-GGCT GCTTCTAAGCCAAC-3') (Massol-Deya et al. 1995). Thermal cycler conditions included $5 \mathrm{~min}$ at $95^{\circ} \mathrm{C}$, followed by 35 cycles consisting of denaturation for $30 \mathrm{~s}$ at $95^{\circ} \mathrm{C}$, primer annealing for $1 \mathrm{~min}$ at $55^{\circ} \mathrm{C}$, and polymerization for $2 \mathrm{~min}$ at $72^{\circ} \mathrm{C}$, with a final extension of $10 \mathrm{~min}$ at $72^{\circ} \mathrm{C}$. After checking DNA quality by gel electrophoresis, $5 \mu \mathrm{l}$ of PCR products were digested with $5 \mathrm{U}$ of the restriction enzymes AluI, HhaI, and RsaI, used in individual reactions and incubated for at least $2 \mathrm{~h}$ at $37^{\circ} \mathrm{C}$. The resulting DNA fragment patterns were visualized on $2 \%$ (wt/vol) agarose in TBE after gel electrophoresis $(100 \mathrm{~V}$, $200 \mathrm{~min}$ ). To further characterize seed epiphytes, $\operatorname{gyr} B$ genes were amplified using a mixture of universal degenerate primers: UP1 (5'-GAAGTCATCATGACCGTTCTGCAYGCNGGNGG NAARTTYGA-3'), UP1G (5'-GAAGTCATCATGACCGTTCT GCAYGCNGGNGGNAARTTYGG-3'), UP2r (5'-AGCAGGG TACGGATGTGCGAGCCRTCNACRTCNGCRTCNGTCAT-3') and UP2Ar (5'-AGCAGGGTACGGATGTGCGAGCCRTCNA CRTCNGCRTCNGYCAT-3') (Yamamoto and Harayama 1995). Primers were added to reaction mixtures prepared as reported for the other PCR assays. Cycler conditions included $5 \mathrm{~min}$ at $95^{\circ} \mathrm{C}$ and 35 cycles consisting of $1 \mathrm{~min}$ at $95^{\circ} \mathrm{C}, 1 \mathrm{~min}$ at $58^{\circ} \mathrm{C}$, and $2 \mathrm{~min}$ at $72^{\circ} \mathrm{C}$, followed by a final elongation step of $10 \mathrm{~min}$ at $72^{\circ} \mathrm{C}$. The approximately 1,200-bp-long PCR products were visualized by electrophoresis on $1 \%(\mathrm{wt} / \mathrm{vol})$ agarose gel and were sequenced with the Sanger method (GATC Biotech AG, Konstanz, Germany), using primers UP1S (5'-GAAGTCATCATGACCGTT CTGCAY-3') and UP2rS (5'-AGCAGGGTACGGATGTGC GAGCC-3'). The quality of sequence chromatograms was evaluated using the sequence alignment editor software BioEdit. 
Sequences that showed reliable quality were further processed, aligned, and trimmed with BioEdit. Finally, to identify the closest related species of seed epiphytes, BLASTN algorithm on the National Center for Biotechnology Information sequence repository was run for nucleotide search in 2017 , excluding sequences from uncultured/environmental samples.

Statistical analyses. Data were assessed for significance $(\alpha=$ 0.05 ) by Student's $t$ tests and one-way analysis of variance combined with Tukey's honest significant difference (HSD) tests for post hoc comparisons of means, using the SPSS Statistics 24 software package (IBM, Armonk, NY, U.S.A.). The assumption of normal distribution was assessed by the ShapiroWilk test and analysis of QQ-plots. The assumption of homoscedasticity of variance across groups was ascertained through Levene's test and analysis of the residuals plotted against fitted values. To correct for heteroscedasticity, arithmetical transformations (e.g., $\log _{10}$, square root) were applied to the data before analysis. Whenever this was not possible, bias-corrected accelerated bootstrap analyses were run with a sample size of $10^{5}$ and two different seeds (i.e., 2000 and 200), using the Mersenne Twister random number generator. The generated 95\% confidence intervals showed sensitivity to both seeds at the first decimal digit. Alternatively, whenever data were not normally distributed, results were tested for significance by the nonparametric Kruskal-Wallis rank variance analysis, followed by Tukey's HSD tests for post hoc comparisons of ranks. The $P$ values for Kruskal-Wallis analyses were adjusted by the Bonferroni correction for multiple tests.

\section{ACKNOWLEDGMENTS}

The authors gratefully thank M. Pastar and M. Polt (AIT) for technical support in 16S rRNA gene amplification, B. Knoll (University of Innsbruck) for skillful assistance with the seedling inoculation experiment, and G. Pichler (University of Innsbruck) for helping to acquire pictures. The authors also acknowledge P. Vaccino (CREA, Italy) for providing T. aestivum seeds, and Hoopman Equipment \& Engineering for conducting the BioFlash seed treatment.

\section{AUTHOR-RECOMMENDED INTERNET RESOURCES}

FAO website: http://www.fao.org/faostat/en/\#home

Ribosome Database Project (RDP) Classifier: https://rdp.cme.msu.edu

\section{LITERATURE CITED}

Alhasawi, A., Leblanc, M., Appanna, N. D., Auger, C., and Appanna, V. D. 2015. Aspartate metabolism and pyruvate homeostasis triggered by oxidative stress in Pseudomonas fluorescens: A functional metabolomic study. Metabolomics 11:1792-1801.

Alquéres, S., Meneses, C., Rouws, L., Rothballer, M., Baldani, I., Schmid, M., and Hartmann, A. 2013. The bacterial superoxide dismutase and glutathione reductase are crucial for endophytic colonization of rice roots by Gluconacetobacter diazotrophicus PAL5. Mol. Plant-Microbe Interact. 26:937-945.

Araújo, W. L., Santos, D. S., Dini-Andreote, F., Salgueiro-Londoño, J. K., Camargo-Neves, A. A., Andreote, F. D., and Dourado, M. N. 2015. Genes related to antioxidant metabolism are involved in Methylobacterium mesophilicum-soybean interaction. Antonie van Leeuwenhoek 108:951-963.

Bahin, E., Bailly, C., Sotta, B., Kranner, I., Corbineau, F., and Leymarie, J. 2011. Crosstalk between reactive oxygen species and hormonal signalling pathways regulates grain dormancy in barley. Plant Cell Environ. 34:980-993.

Bailly, C., El-Maarouf-Bouteau, H., and Corbineau, F. 2008. From intracellular signaling networks to cell death: The dual role of reactive oxygen species in seed physiology. C. R. Biol. 331:806-814.

Bailly, C., and Kranner, I. 2011. Analyses of Reactive Oxygen Species and Antioxidants in Relation to Seed Longevity and Germination. Springer, Berlin.

Baker, K. F. 1969. Aerated-steam treatment of seed for disease control. Hortic. Res. 9:59-73.
Barret, M., Briand, M., Bonneau, S., Préveaux, A., Valière, S., Bouchez, O., Hunault, G., Simoneau, P., and Jacquesa, M. A. 2015. Emergence shapes the structure of the seed microbiota. Appl. Environ. Microbiol. 81:1257-1266.

Barret, M., Guimbaud, J. F., Darrasse, A., and Jacques, M. A. 2016. Plant microbiota affects seed transmission of phytopathogenic microorganisms. Mol. Plant Pathol. 17:791-795.

Bergna, A., Cernava, T., Rändler, M., Grosch, R., Zachow, C., and Berg, G. 2018. Tomato seeds preferably transmit plant beneficial endophytes. Phytobiomes J 2:183-193.

Bewley, J. D. 1997. Seed germination and dormancy. Plant Cell 9: 1055-1066.

Bhagat, J., Kaur, A., and Chadha, B. S. 2016. Single step purification of asparaginase from endophytic bacteria Pseudomonas oryzihabitans exhibiting high potential to reduce acrylamide in processed potato chips. Food Bioprod. Process. 99:222-230.

Bigeard, J., Colcombet, J., and Hirt, H. 2015. Signaling mechanisms in pattern-triggered immunity (PTI). Mol. Plant 8:521-539.

Bordenstein, S. R., and Theis, K. R. 2015. Host biology in light of the microbiome: Ten principles of holobionts and hologenomes. PLoS Biol. 13:e1002226

Brader, G., Compant, S., Mitter, B., Trognitz, F., and Sessitsch, A. 2014 Metabolic potential of endophytic bacteria. Curr. Opin. Biotechnol. 27:30-37.

Brader, G., Compant, S., Vescio, K., Mitter, B., Trognitz, F., Ma, L. J., and Sessitsch, A. 2017. Ecology and genomic insights into plant-pathogenic and plant-nonpathogenic endophytes. Annu. Rev. Phytopathol. 55:61-83.

Camejo, D., Guzmán-Cedeño, Á., and Moreno, A. 2016. Reactive oxygen species, essential molecules, during plant-pathogen interactions. Plant Physiol. Biochem. 103:10-23.

Compant, S., Mitter, B., Colli-Mull, J. G., Gangl, H., and Sessitsch, A. 2011. Endophytes of grapevine flowers, berries, and seeds: Identification of cultivable bacteria, comparison with other plant parts, and visualization of niches of colonization. Microb. Ecol. 62:188-197.

Cope-Selby, N., Cookson, A., Squance, M., Donnison, I., Flavell, R., and Farrar, K. 2017. Endophytic bacteria in Miscanthus seed: Implications for germination, vertical inheritance of endophytes, plant evolution and breeding. GCB Bioenergy 9:57-77.

Cottyn, B., Debode, J., Regalado, E., Mew, T. W., and Swings, J. 2009. Phenotypic and genetic diversity of rice seed-associated bacteria and their role in pathogenicity and biological control. J. Appl. Microbiol. 107:885-897.

Díaz Herrera, S., Grossi, C., Zawoznik, M., and Groppa, M. D. 2016. Wheat seeds harbour bacterial endophytes with potential as plant growth promoters and biocontrol agents of Fusarium graminearum. Microbiol. Res. 186-187:37-43.

Dutkiewicz, J., Mackiewicz, B., Lemieszek, M. K., Golec, M., Skórska, C., Góra-Florek, A., and Milanowski, J. 2016. Pantoea agglomerans: A mysterious bacterium of evil and good. Part II-Deleterious effects: Dust-borne endotoxins and allergens-Focus on grain dust, other agricultural dusts and wood dust. Ann. Agric. Environ. Med. 23:6-29.

Edwards, U., Rogall, T., Blöcker, H., Emde, M., and Böttger, E. C. 1989. Isolation and direct complete nucleotide determination of entire genes. Characterization of a gene coding for $16 \mathrm{~S}$ ribosomal RNA. Nucleic Acids Res. 17:7843-7853.

Elsayed, Y., Refaat, J., Abdelmohsen, U. R., and Fouad, M. A. 2017. The genus Rhodococcus as a source of novel bioactive substances: A review. J Pharmacogn Phytochemistry. 6:83-92.

Foreman, J., Demidchik, V., Bothwell, J. H. F., Mylona, P., Miedema, H., Torres, M. A., Linstead, P., Costa, S., Brownlee, C., Jones, J. D. G., Davies, J. M., and Dolan, L. 2003. Reactive oxygen species produced by NADPH oxidase regulate plant cell growth. Nature 422:442-446.

Forsberg, G., Andersson, S., and Johnsson, L. 2002. Evaluation of hot, humid air seed treatment in thin layers and fluidized beds for seed pathogen sanitation. Z Pflanzenk Pflanzen 109:357-370.

Forsberg, G., Johnsson, L., and Lagerholm, J. 2005. Effects of aerated steam seed treatment on cereal seed-borne diseases and crop yield. $\mathrm{Z}$ Pflanzenk Pflanzen 112:247-256.

Garcia-Brugger, A., Lamotte, O., Vandelle, E., Bourque, S., Lecourieux, D., Poinssot, B., Wendehenne, D., and Pugin, A. 2006. Early signaling events induced by elicitors of plant defenses. Mol. Plant-Microbe Interact. 19:711-724.

Gerna, D., Roach, T., Arc, E., Stöggl, W., Limonta, M., Vaccino, P., and Kranner, I. 2018. Redox poise and metabolite changes in bread wheat seeds are advanced by priming with hot steam. Biochem. J. 475: 3725-3743.

Gerna, D., Roach, T., Stöggl, W., Wagner, J., Vaccino, P., Limonta, M., and Kranner, I. 2017. Changes in low-molecular-weight thiol-disulphide redox couples are part of bread wheat seed germination and early seedling growth. Free Radic. Res. 51:568-581. 
Grady, E. N., MacDonald, J., Liu, L., Richman, A., and Yuan, Z. C. 2016. Current knowledge and perspectives of Paenibacillus: A review. Microb. Cell Fact. 15:203.

Grant, J. J., and Loake, G. J. 2000. Role of reactive oxygen intermediates and cognate redox signaling in disease resistance. Plant Physiol. 124:21-29.

Groot, S. P. C., Birnbaum, Y., Rop, N., Jalink, H., Forsberg, G. Kromphardt, C., Werner, S., and Koch, E. 2006. Effect of seed maturity on sensitivity of seeds towards physical sanitation treatments. Seed Sci. Technol. 34:403-413.

Halmer, P. 2006. Seed technology and seed enhancement. Acta Hortic.: 17-26.

Hammond-Kosack, K. E., and Jones, J. D. G. 1996. Resistance genedependent plant defense responses. Plant Cell 8:1773-1791.

Hardoim, P. R., Hardoim, C. C. P., van Overbeek, L. S., and van Elsas, J. D. 2012. Dynamics of seed-borne rice endophytes on early plant growth stages. PLoS One 7:e30438.

Hardoim, P. R., van Overbeek, L. S., Berg, G., Pirttilä, A. M., Compant, S., Campisano, A., Döring, M., and Sessitsch, A. 2015. The hidden world within plants: Ecological and evolutionary considerations for defining functioning of microbial endophytes. Microbiol. Mol. Biol. Rev. 79:293-320.

Ho, A., Di Lonardo, D. P., and Bodelier, P. L. E. 2017. Revisiting life strategy concepts in environmental microbial ecology. FEMS Microbiol. Ecol. 93:93.

Imlay, J. A. 2015. Diagnosing oxidative stress in bacteria: Not as easy as you might think. Curr. Opin. Microbiol. 24:124-131.

Ishibashi, Y., Tawaratsumida, T., Zheng, S. H., Yuasa, T., and Iwaya-Inoue, M. 2010. NADPH oxidases act as key enzyme on germination and seedling growth in barley (Hordeum vulgare L.). Plant Prod. Sci. 13:45-52.

Johnston-Monje, D., and Raizada, M. N. 2011. Conservation and diversity of seed associated endophytes in Zea across boundaries of evolution, ethnography and ecology. PLoS One 6:e20396.

Kandel, S. L., Joubert, P. M., and Doty, S. L. 2017. Bacterial endophyte colonization and distribution within plants. Microorganisms 5:77.

Khare, E., Mishra, J., and Arora, N. K. 2018. Multifaceted interactions between endophytes and plant: Developments and prospects. Front. Microbiol. 9:2732.

Koch, E., Schmitt, A., Stephan, D., Kromphardt, C., Jahn, M., Krauthausen, H. J., Forsberg, G., Werner, S., Amein, T., Wright, S. A. I., Tinivella, F., Gullino, M. L., Roberts, S. J., van der Wolf, J., and Groot, S. P. C. 2010. Evaluation of non-chemical seed treatment methods for the control of Alternaria dauci and A. radicina on carrot seeds. Eur. J. Plant Pathol. 127:99-112.

Kodama, K., Kimura, N., and Komagata, K. 1985. Two new species of Pseudomonas: P. oryzihabitans isolated from rice paddy and clinical specimens and $P$. luteola isolated from clinical specimens. Int. J. Syst. Bacteriol. 35:467-474.

Kranner, I., Minibayeva, F. V., Beckett, R. P., and Seal, C. E. 2010a. What is stress? Concepts, definitions and applications in seed science. New Phytol. 188:655-673.

Kranner, I., Roach, T., Beckett, R. P., Whitaker, C., and Minibayeva, F. V. 2010b. Extracellular production of reactive oxygen species during seed germination and early seedling growth in Pisum sativum. J. Plant Physiol. 167:805-811.

Laino, P., Limonta, M., Gerna, D., and Vaccino, P. 2015. Morphophysiolological and qualitative traits of a bread wheat collection spanning a century of breeding in Italy. Biodivers. Data J. 14:e4760.

Lamb, C., and Dixon, R. A. 1997. The oxidative burst in plant disease resistance. Annu. Rev. Plant Physiol. Plant Mol. Biol. 48:251-275.

Lane, D. J. 1991. 16S/23S rRNA Sequencing. John Wiley and Sons, Chichester.

Lei, P., Pang, X., Feng, X., Li, S., Chi, B., Wang, R., Xu, Z., and Xu, H. 2017. The microbe-secreted isopeptide poly- $\gamma$-glutamic acid induces stress tolerance in Brassica napus L. seedlings by activating crosstalk between $\mathrm{H}_{2} \mathrm{O}_{2}$ and $\mathrm{Ca}^{2+}$. Sci. Rep. 7:41618.

Levine, A., Tenhaken, R., Dixon, R., and Lamb, C. 1994. $\mathrm{H}_{2} \mathrm{O}_{2}$ from the oxidative burst orchestrates the plant hypersensitive disease resistance response. Cell 79:583-593.

Li, W. Y., Chen, B. X., Chen, Z. J., Gao, Y. T., Chen, Z., and Liu, J. 2017. Reactive oxygen species generated by NADPH oxidases promote radicle protrusion and root elongation during rice seed germination. Int. J. Mol. Sci. 18:E110.

Liu, H., Carvalhais, L. C., Crawford, M., Singh, E., Dennis, P. G., Pieterse, C. M. J., and Schenk, P. M. 2017. Inner plant values: Diversity, colonization and benefits from endophytic bacteria. Front. Microbiol. 8: 2552.

Mano, H., Tanaka, F., Watanabe, A., Kaga, H., Okunishi, S., and Morisaki, H. 2006. Culturable surface and endophytic bacterial flora of the maturing seeds of rice plants (Oryza sativa) cultivated in paddy field. Microbes Environ. 21:86-100.

Manz, B., Müller, K., Kucera, B., Volke, F., and Leubner-Metzger, G. 2005. Water uptake and distribution in germinating tobacco seeds investigated in vivo by nuclear magnetic resonance imaging. Plant Physiol. 138: 1538-1551.

Massol-Deya, A., Odelson, D. A., Hickey, R.F., and Tiedje, J. M. 1995. Bacterial community fingerprinting of amplified $16 \mathrm{~S}$ and $16 \mathrm{~S}-23 \mathrm{~S}$ ribosomal DNA gene sequences and restriction endonuclease analysis (ARDRA). Pages 289-296 in: In: Molecular Microbial Ecology Manual. A. D. L. Akkermans, J. D. Van Elsas, and F. J. De Bruijn, eds. Springer, Dordrecht, The Netherlands.

McDowell, J. M., and Dangl, J. L. 2000. Signal transduction in the plant immune response. Trends Biochem. Sci. 25:79-82.

Mhamdi, A., and Van Breusegem, F. 2018. Reactive oxygen species in plant development. Development 145:dev164376.

Mitter, B., Petric, A., Shin, M. W., Chain, P. S. G., Hauberg-Lotte, L., Reinhold-Hurek, B., Nowak, J., and Sessitsch, A. 2013. Comparative genome analysis of Burkholderia phytofirmans PsJN reveals a wide spectrum of endophytic lifestyles based on interaction strategies with host plants. Front. Plant Sci. 4:120.

Mitter, B., Pfaffenbichler, N., Flavell, R., Compant, S., Antonielli, L., Petric, A., Berninger, T., Naveed, M., Sheibani-Tezerji, R., von Maltzahn, G., and Sessitsch, A. 2017. A new approach to modify plant microbiomes and traits by introducing beneficial bacteria at flowering into progeny seeds. Front. Microbiol. 8:11.

Morkunas, I., Bednarski, W., and Kozłowska, M. 2004. Response of embryo axes of germinating seeds of yellow lupine to Fusarium oxysporum. Plant Physiol. Biochem. 42:493-499.

Müller, K., Linkies, A., Vreeburg, R. A. M., Fry, S. C., Krieger-Liszkay, A., and Leubner-Metzger, G. 2009. In vivo cell wall loosening by hydroxyl radicals during cress seed germination and elongation growth. Plant Physiol. 150:1855-1865.

Nanda, A. K., Andrio, E., Marino, D., Pauly, N., and Dunand, C. 2010. Reactive oxygen species during plant-microorganism early interactions. J. Integr. Plant Biol. 52:195-204.

Naveed, M., Mitter, B., Yousaf, S., Pastar, M., Afzal, M., and Sessitsch, A. 2014. The endophyte Enterobacter sp FD17: A maize growth enhancer selected based on rigorous testing of plant beneficial traits and colonization characteristics. Biol. Fertil. Soils 50:249-262.

Nelson, E. B. 2004. Microbial dynamics and interactions in the spermosphere. Annu. Rev. Phytopathol. 42:271-309.

Nelson, E. B. 2018. The seed microbiome: Origins, interactions, and impacts. Plant Soil 422:7-34.

Nonogaki, H., Bassel, G. W., and Bewley, J. D. 2010. Germination - still a mystery. Plant Sci. 179:574-581.

Okunishi, S., Sako, K., Mano, H., Imamura, A., and Morisaki, H. 2005. Bacterial flora of endophytes in the maturing seed of cultivated rice (Oryza sativa). Microbes Environ. 20:168-177.

Ortmann, I., Conrath, U., and Moerschbacher, B. M. 2006. Exopolysaccharides of Pantoea agglomerans have different priming and eliciting activities in suspension-cultured cells of monocots and dicots. FEBS Lett. 580:4491-4494.

Ortmann, I., and Moerschbacher, B. M. 2006. Spent growth medium of Pantoea agglomerans primes wheat suspension cells for augmented accumulation of hydrogen peroxide and enhanced peroxidase activity upon elicitation. Planta 224:963-970.

Pauly, N., Pucciariello, C., Mandon, K., Innocenti, G., Jamet, A., Baudouin, E., Hérouart, D., Frendo, P., and Puppo, A. 2006. Reactive oxygen and nitrogen species and glutathione: Key players in the legume-Rhizobium symbiosis. J. Exp. Bot. 57:1769-1776.

Pel, M. J. C., and Pieterse, C. M. J. 2013. Microbial recognition and evasion of host immunity. J. Exp. Bot. 64:1237-1248.

Rahman, M. M., Flory, E., Koyro, H. W., Abideen, Z., Schikora, A., Suarez, C., Schnell, S., and Cardinale, M. 2018. Consistent associations with beneficial bacteria in the seed endosphere of barley (Hordeum vulgare L.). Syst. Appl. Microbiol. 41:386-398.

Rathjen, J. R., Strounina, E. V., and Mares, D. J. 2009. Water movement into dormant and non-dormant wheat (Triticum aestivum L.) grains. J. Exp. Bot. 60:1619-1631.

Reinhold-Hurek, B., and Hurek, T. 2011. Living inside plants: Bacterial endophytes. Curr. Opin. Plant Biol. 14:435-443.

Roach, T., Beckett, R. P., Minibayeva, F. V., Colville, L., Whitaker, C., Chen, H., Bailly, C., and Kranner, I. 2010. Extracellular superoxide production, viability and redox poise in response to desiccation in recalcitrant Castanea sativa seeds. Plant Cell Environ. 33: 59-75. 
Roach, T., Colville, L., Beckett, R. P., Minibayeva, F. V., Havaux, M., and Kranner, I. 2015. A proposed interplay between peroxidase, amine oxidase and lipoxygenase in the wounding-induced oxidative burst in Pisum sativum seedlings. Phytochemistry 112:130-138.

Rodríguez, C. E., Mitter, B., Barret, M., Sessitsch, A., and Compant, S. 2018. Commentary: Seed bacterial inhabitants and their routes of colonization. Plant Soil 422:129-134.

Rodriguez-Bravo, S., and Pionetti, J. M. 1981. Inducible catalase in Pseudomonas fluorescens. Biochimie 63:535-540.

Ryan, R. P., Monchy, S., Cardinale, M., Taghavi, S., Crossman, L., Avison, M. B., Berg, G., van der Lelie, D., and Dow, J. M. 2009. The versatility and adaptation of bacteria from the genus Stenotrophomonas. Nat. Rev. Microbiol. 7:514-525.

Sambrook, J. F., and Russel, D. W. 2001. Molecular Cloning: A Laboratory Manual. Cold Spring Harbor Laboratory Press, New York.

Santoyo, G., Moreno-Hagelsieb, G., Orozco-Mosqueda, M. C., and Glick, B. R. 2016. Plant growth-promoting bacterial endophytes. Microbiol. Res. 183:92-99.

Schiltz, S., Gaillard, I., Pawlicki-Jullian, N., Thiombiano, B., Mesnard, F., and Gontier, E. 2015. A review: What is the spermosphere and how can it be studied? J. Appl. Microbiol. 119:1467-1481.

Sessitsch, A., Hardoim, P., Döring, J., Weilharter, A., Krause, A., Woyke, T., Mitter, B., Hauberg-Lotte, L., Friedrich, F., Rahalkar, M., Hurek, T., Sarkar, A., Bodrossy, L., van Overbeek, L., Brar, D., van Elsas, J. D., and Reinhold-Hurek, B. 2012. Functional characteristics of an endophyte community colonizing rice roots as revealed by metagenomic analysis. Mol. Plant-Microbe Interact. 25:28-36

Shade, A., Jacques, M. A., and Barret, M. 2017. Ecological patterns of seed microbiome diversity, transmission, and assembly. Curr. Opin. Microbiol. 37:15-22.

Shahzad, R., Khan, A. L., Bilal, S., Asaf, S., and Lee, I. J. 2018. What is there in seeds? Vertically transmitted endophytic resources for sustainable improvement in plant growth. Front. Plant Sci. 9:24.

Sheibani-Tezerji, R., Naveed, M., Jehl, M. A., Sessitsch, A., Rattei, T., and Mitter, B. 2015. The genomes of closely related Pantoea ananatis maize seed endophytes having different effects on the host plant differ in secretion system genes and mobile genetic elements. Front. Microbiol. 6:440.

Singh, R. P., and Jha, P. N. 2017. The PGPR Stenotrophomonas maltophilia SBP-9 augments resistance against biotic and abiotic stress in wheat plants. Front. Microbiol. 8:1945.

Singh, R., Singh, S., Parihar, P., Mishra, R. K., Tripathi, D. K., Singh, V. P., Chauhan, D. K., and Prasad, S. M. 2016. Reactive oxygen species (ROS): Beneficial companions of plants' developmental processes. Front. Plant Sci. 7:1299.

Taghavi, S., van der Lelie, D., Hoffman, A., Zhang, Y. B., Walla, M. D., Vangronsveld, J., Newman, L., and Monchy, S. 2010. Genome sequence of the plant growth promoting endophytic bacterium Enterobacter sp. 638. PLoS Genet. 6:e1000943.

Torres-Cortés, G., Bonneau, S., Bouchez, O., Genthon, C., Briand, M., Jacques, M. A., and Barret, M. 2018. Functional microbial features driving community assembly during seed germination and emergence. Front. Plant Sci. 9:902.
Truyens, S., Weyens, N., Cuypers, A., and Vangronsveld, J. 2015. Bacterial seed endophytes: Genera, vertical transmission and interaction with plants. Environ. Microbiol. Rep. 7:40-50.

van der Heijden, J., Vogt, S. L., Reynolds, L. A., Peña-Díaz, J., Tupin, A., Aussel, L., and Finlay, B. B. 2016. Exploring the redox balance inside gram-negative bacteria with redox-sensitive GFP. Free Radic. Biol. Med. 91:34-44

Verma, S. K., Kharwar, R. N., and White, J. F. 2019. The role of seedvectored endophytes in seedling development and establishment. Symbiosis 78:107-113.

Walitang, D. I., Kim, K., Madhaiyan, M., Kim, Y. K., Kang, Y., and Sa, T. 2017. Characterizing endophytic competence and plant growth promotion of bacterial endophytes inhabiting the seed endosphere of rice. BMC Microbiol. 17:209.

Walterson, A. M., and Stavrinides, J. 2015. Pantoea: Insights into a highly versatile and diverse genus within the Enterobacteriaceae. FEMS Microbiol. Rev. 39:968-984.

Wang, Q., Garrity, G. M., Tiedje, J. M., and Cole, J. R. 2007. Naive Bayesian classifier for rapid assignment of rRNA sequences into the new bacterial taxonomy. Appl. Environ. Microbiol. 73: 5261-5267.

Wassermann, B., Müller, H., and Berg, G. 2019. An apple a day: Which bacteria do we eat with organic and conventional apples? Front. Microbiol. 10:1629.

Watts, J. E., Devilliers, O. T., and Watts, L. 1993. Sterilization of wheat seeds for tissue culture purposes. S. Afr. J. Bot. 59:641-642.

Weitbrecht, K., Müller, K., and Leubner-Metzger, G. 2011. First off the mark: Early seed germination. J. Exp. Bot. 62:3289-3309.

White, T. J., Bruns, T. D., Lee, S., and Taylor, J. 1990. Amplification and sequencing of fungal ribosomal RNA genes for phylogenetics. Pages 315-322 in: PCR Protocols: A Guide to Methods and Applications, eds M. A. Innis, D. H. Gelfand, D. H. Gelfand, J. J. Sninsky, and T. J. White, eds. Academic Press, San Diego, CA, U.S.A.

Wojtaszek, P. 1997. Oxidative burst: An early plant response to pathogen infection. Biochem. J. 322:681-692.

Wojtyla, Ł., Lechowska, K., Kubala, S., and Garnczarska, M. 2016. Different modes of hydrogen peroxide action during seed germination. Front. Plant Sci. 7:66.

Yamamoto, S., and Harayama, S. 1995. PCR amplification and direct sequencing of $g y r B$ genes with universal primers and their application to the detection and taxonomic analysis of Pseudomonas putida strains. Appl. Environ. Microbiol. 61:3768.

Yang, L., Danzberger, J., Schöler, A., Schröder, P., Schloter, M., and Radl, V. 2017. Dominant groups of potentially active bacteria shared by barley seeds become less abundant in root associated microbiome. Front. Plant Sci. 8:1005.

Zadoks, J. C., Chang, T. T., and Konzak, C. F. 1974. Decimal code for growth stages of cereals. Weed Res. 14:415-421.

Zamocky, M., Furtmüller, P. G., and Obinger, C. 2008. Evolution of catalases from bacteria to humans. Antioxid. Redox Signal. 10:1527-1548.

Zilber-Rosenberg, I., and Rosenberg, E. 2008. Role of microorganisms in the evolution of animals and plants: The hologenome theory of evolution. FEMS Microbiol. Rev. 32:723-735. 